\title{
Crustal seismic structure beneath Portugal and Southern Galicia (Western Iberia) and the role of Variscan inheritance
}

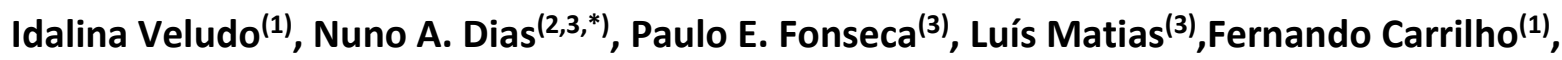 \\ Christian Haberland ${ }^{(4)}$, Antonio Villaseñor ${ }^{(5)}$
}

1. Instituto Português do Mar e da Atmosfera, I.P., Rua C ao Aeroporto, 1749-077 Lisbon, Portugal

2. Instituto Superior de Engenharia de Lisboa - ISEL,Instituto Politécnico de Lisboa, R. Conselheiro Emídio Navarro, 1959-007 Lisbon, Portugal

3. Instituto Dom Luiz, Faculdade de Ciências, Universidade de Lisboa, Campo Grande, Ed. C1, Piso 1, 1749-016, Lisbon, Portugal.

4. GeoForschungsZentrum - GFZ, Potsdam, Germany.

5. Institute of Earth Sciences Jaume Almera, ICTJA-CSIC, Barcelona, Spain.

*Corresponding author: Nuno Afonso Dias. Instituto Superior de Engenharia de Lisboa, R. Conselheiro Emídio Navarro, 1959-007 Lisbon, Portugal.Tel.:+351 218317 135; Fax+.:351 218 317 138; E-mails: ndias@adf.isel.pt; nmdias@fc.ul.pt

Other E-mail addresses: Idalina.veludo@ipma.pt(I. Veludo);Immatias@fc.ul.pt (L. Matias); pefonseca@fc.ul.pt (P. E. Fonseca);fernando.carrilho@ipma.pt (F. Carrilho); haber@gfzpotsdam.de (C. Haberland); antonio.villasenor@csic.es (A. Villaseñor) 

western border of Iberia (Pereira et al., 2016; Ribeiro et al., 1990).

Since the Miocene, the southern interaction between Africa and Iberia is characterized by a

14 The oblique convergence between the two plates occurs at a slow rate of 3-6 mmyr ${ }^{-1}$ 15 (Fernandes, 2003; Nocquet, 2012; Serpelloni et al., 2007), resulting in a slow deformation regime whose manifestation is a seismicity rate that increases in number and magnitude

The impact and extension of this complex tectonics in the structure of the Iberian lithosphere is still a matter of discussion, especially in its western part beneath Portugal. The existing knowledge relating the observed surface geology and lithospheric deep structures is sparse and sometimes incoherent, the relation between shallow and deep structures and their lateral extension still widely undetermined. the seismicity in the areas closer to the plate boundary was to be expected, the concentration of seismicity along the western lberian margin and its clustering in some specific places reveals an anomalous pattern not yet fully understood.

8 Some questions still pertinent are the role and influence of the several tectonic units, and 9 their contacts, in the present tectonic regime and the stress field observed today and the 31 inherited structure from past orogenies. 
To address these questions, and taking advantage of an accumulated dataset of the seismicity recorded over the last 15 years (cf. Fig.1), we have conducted a local earthquake

34 tomographic study of the crust beneath Portugal.

\section{Geological and tectonic framework}

The majority of lithological units outcropping in Western Iberia are of Paleozoic age (480-290 $\mathrm{Ma}$ ) and compose the Iberian Massif or Iberian Autochthonous Terrane, the major outcrop of the SW European Variscides (Fernández et al., 2016; Matte, 2001, 1986; Ribeiro et al., 2007). In Portugal, the Iberian Massif can be divided in four main tectonic units, from north to south (cf. Fig.2): the Galicia-Trás-os-Montes Zone (GTMZ), which consists of a pile of allochthonous thrust sheets, overlying the autochthonous Central Iberian Zone (ClZ), the paraautochtnonous Ossa-Morena Zone (OMZ) and the allochthonous South Portuguese Zone (SPZ) (Arenas et al., 2016b; Dias and Ribeiro, 1995; Ribeiro et al., 2007; Simancas et al., 2001).

The actual tectono-structural outline of the $\mathrm{W}$ edge of Iberian Peninsula (Portugal) is the result of three main orogenic events: Cadomian orogeny (660-540 My) (Linnemann et al., 2008; Ribeiro et al., 2009), Variscan Orogeny (380-280 My) (Arenas et al., 2016a; Simancas et al., 2013) and Alpine orogeny (125-37My) (Jeanniot et al., 2016; Pereira et al., 2016; Pereira and Alves, 2013). The main and most important orogenic event that delineates all the major faults of the territory and tectonic shape is the Variscan event. Characteristically, the Paleozoic collision episode began during the upper Devonian and ended at the Pennsylvanian period (Upper Carboniferous). Since then almost all the reactivation of fault zones takes into account the previous scenario of the three main Variscan tectonic and deformation phases and the last tardi-Variscan fracturation. The Alpine orogeny is controlled by previous orogenic heritage (Miranda et al., 2009; Nance et al., 2010; Pais et al., 2012; Pereira et al., 2016; Wilson, 1966).

60

61 The impact of this complex assemblage in the structure of the lithosphere and the 62 topography of some of its inner discontinuities, namely the Moho, has mostly been 
63 addressed through controlled-source experiments (e.g., Banda, 1988; Díaz et al., 1993a;

64 Mueller et al., 1973; Prodehl et al., 1975; Sousa Moreira et al., 1983, 1978; Victor et al., 65 1980), conducted in the 1970's and 1980's and mainly concentrated in the southern part of 66 the country. Matias (1996) made a synthesis of all deep seismic sounding (DSS) results available in Portugal Mainland, revising all previous data with a common methodology. Pwave velocity models were derived from travel-time inversion (Zelt and Smith, 1992) and amplitudes were controlled by synthetic seismograms (Zelt and Ellis, 1988). That study evidenced the limited spatial coverage of these data and showed features that raised some questions: i) the discrepancy between the velocity model and its gravity anomaly in Vila do Bispo (SW tip of Portugal); ii) the upper crust (down to $10 \mathrm{~km}$ depth) is strongly anisotropic in the SPZ; iii) the deep structure and Moho depth in the SPZ show conflicting results between crossing profiles; iv) the $\mathrm{OMZ}$ was interpreted as an upper-crust block on top of lower crust blocks from the SPZ and $\mathrm{CIZ}$. In mainland Portugal, there are no S-wave velocity estimates derived from DSS studies. Téllez and Córdoba (1998) estimated S-wave models for the GTMZ (Spanish side) but the seismic character (reflectivity and amplitude of the Moho reflection) is very different from the ones obtained on the Portuguese side, and its generalization to the whole area is uncertain. DSS analysis in Portugal mainland (Matias, 1996) also suggest that the Moho is nearly everywhere a second order discontinuity due to the absence of precritical PMP reflections, a result that is at odds with what was observed in the Spanish GTMZ (Téllez et al., 1993).

83

84 The DSS results pointed to a Moho discontinuity topography relatively smooth with a progressive thinning from the interior towards the margins, but with some lateral variations. The greater heterogeneity is located in the $\mathrm{OMZ}$, where there is an indication of a crustal thinning relatively to the $\mathrm{ClZ}$ and particularly to the SPZ. The models obtained from the majority of the profiles indicate a three-layer crust, the middle-lower crustal levels showing fairly stable results, the main differences being located at the upper crust; where Vp values range from $6.0-6.3 \mathrm{~km} / \mathrm{s}$, whereas in the middle and lower crust the typical values are around 6.4-6.5 km/s and 6.6-7.0 km/s respectively. Only in areas of thick sedimentary basins, like the LTV are observed Vp values smaller than $5.0 \mathrm{~km} / \mathrm{s}$. 
94 Additional information on the crustal structure has been provided from teleseismic PReceiver Functions (PRFs) studies. Julia and Mejia (2004) estimated Moho depths and Vp/Vs ratio values at five locations in the Iberian Massif, the Paleozoic core of Iberian Peninsula, obtaining an average crustal thickness of $30 \pm 2 \mathrm{~km}$, with an average $\mathrm{Vp} / \mathrm{Vs}$ ratio of $1.74 \pm$ 0.05. Beneath the Lower Tagus Valley, Salah et al. (2011) estimated Moho depths between 25.5 and $30 \mathrm{~km}$ and $\mathrm{Vp} / \mathrm{Vs}$ ratio variations between 1.65 and 1.81 , with an average of 1.75 . More recently, in the framework of project WILAS (Dündar et al., 2016), the values of Moho depth and $\mathrm{Vp} / \mathrm{Vs}$ average crustal ratio were derived covering the entire country; the image provided points to a relatively smooth Moho overall consistent with the DSS values, although with some misfits, whereas the major variations in $\mathrm{Vp} / \mathrm{Vs}$ appear associated with the structure of the $\mathrm{OMZ}$ or beneath the basins at the continental margin.

105

Discrepancies between DSS velocity models (Matias, 1996) and PRF results (Dündar et al., 107 2016; Salah et al., 2011), mainly for the Lower Tagus Valley and the SE region of Portugal, also raise the question of how these two datasets can be compared. PRFs are most sensitive to the S-wave velocities and use lower frequencies than controlled source active seismic surveys.

More recently several studies have been performed at smaller scales, mainly in the area of the Lower Tagus Valley (Borges et al., 2016; Carvalho et al., 2016, 2014, 2008; Ghose et al., 2013), due to this region being a potential seismogenic area for Lisbon. These studies show the presence of an uplifted area to the NW of the Tagus Valley and a thick sedimentary basin to the SE.

\section{Data selection}

The seismicity in Portugal is interpreted nowadays as the result of the convergence regime between the Eurasia and African plates, its rate, depth distribution and magnitude increasing from north to south, the biggest and deeper events being located in the offshore. Inland, the seismicity rarely exceeds magnitude 4 or depths greater than 20 km (cf. Fig.3 left). 
Since 2007 the permanent seismic network operating in Portugal has increased in number and quality, currently comprising over 30 stations, the majority being broadband and operated by IPMA-Instituto Português do Mar e da Atmosfera (network code PM), the Portuguese official entity responsible for seismological surveillance, with additional stations belonging to the universities of Lisbon, Évora and Coimbra (network codes LX, IP, SS and WM). Between 2010 and 2012 a temporary network of 20 BB stations operated within project WILAS, an experiment designed to complement the Spanish TOPOIBERIA initiative (cf. Fig3. right; see details in Custodio et al., 2014; Custódio et al., 2015; Diaz et al., 2010).

The data used in this study correspond to the seismic catalogue of IPMA for the period 20002014 (cf. Fig.3 left), which was formed using all permanent seismic stations that operated in

Portugal in that period coupled with the permanent Spanish stations closer to the border. In the period 2010-2013 the dataset was complemented with readings from the temporary stations of the WILAS project and some of the TOPOIBERIA project (cf. Fig.3 right).

There is some discussion on the usage of off-side network events, i.e., earthquakes with an azimuthal GAP $>180^{\circ}$; while a GAP $<180^{\circ}$ increases the hypocentral solution confidence (e.g. Hunsen, 1999; Kissling et al., 1994), it may exclude valuable information that could be used in the 3D modeling (Koulakov, 2009).

For the data selection criteria we opted for a compromise approach, i.e., increase the GAP limit to 200 o but limiting the events to distances of $50 \mathrm{~km}$ from the modeled volume (cf. Fig. 3 right). The total number of additional events added this way is small, less than $2 \%$ of the total, the main advantage being the inclusion of some events at the 180 threshold.

Since the seismicity rate is not uniform, the minimum number of stations/phase readings used in the selection was variable: for events located south of 399 $\mathrm{N}$ that number was set to a minimum of 8 stations and 10 readings of either P- or S-phases, whereas for events located north these numbers were reduced to 6 stations and 8 readings. All events with an RMS>0.7 were checked, eventually with correction or rejection of the phase-picks. This resulted on the selection of 1381 events in the south, and 1282 in the north, reaching a total of 2663 events; 
also rejected, with the final dataset being reduced to 2640 events comprising $28062 \mathrm{P}$ - and 21165 S-phase readings.

The ray-density distribution provided by the combined selected dataset shows a relatively uniform distribution in the south and an irregular distribution in the north, with a hiatus in central Portugal (cf. Figures S1 and S2 in supplementary material). Therefore the 3D grid built for the tomographic inversion has an irregular spacing: south of 399 $\mathrm{N}$ being uniform with an horizontal distance between nodes of $20 \mathrm{~km}$ in both directions, whereas to the north it varies between $20 \mathrm{~km}$ in the W-E direction and $40-80 \mathrm{~km}$ in the N-S direction (cf. Fig.3 right).

The standard tomographic methods assume that picked phases correspond to refracted direct first arrivals which, coupled with the criteria stated above and the expected relation between increasing magnitude and number of events, would imply that all $\mathrm{P}$ and $\mathrm{S}$ phases of the selected events correspond indeed to first arrivals. However, as the epicentral distance increases, the amplitude of the seismic waves and the signal-to-noise ratio decreases, and the harder it gets to pick the onset of the first arrivals of both the $\mathrm{P}$ and $\mathrm{S}$ phases. Since the majority of the selected events correspond to microseismicity, rarely exceeding the magnitude of 3.5, the amplitude of the first arrivals is often of the same amplitude of the seismic noise, in particular for distances greater than $150 \mathrm{~km}$ where the first arrivals correspond to $\mathrm{Pn}$ or Sn phases (cf. Fig.4). Also, the number of stations recording an event depend not only on the magnitude of the event but also on the operational status of the network, which strongly varied along the evaluated period. As a result, some of the available picks do not correspond to first arrivals ( $\mathrm{Pg}, \mathrm{Pn}$ ) but actually to secondary arrivals, either refracted or reflected (like the PmP); since the LET method assumes that the $\mathrm{P}$ and $\mathrm{S}$ picks correspond to first arrivals, the usage of a secondary arrivals will result on unrealistic slower velocity areas in order to accommodate the longer time traveling periods (cf. Fig. 4).

184 Using the arrivals of the strongest events as guide, all picks corresponding to the more distant events marked as first arrivals but consistent with secondary arrivals (probably Pg or PmP phases) were removed; since these correspond to the deeper travel-paths, penetrating in the lower crust and upper mantle, the consequence was to severely limit the depth 
imaging capability. For this reason in the final model the lower crust and upper mantle are outside of the resolved areas.

\section{Methodology}

The tomographic method used correspond to the widely used and tested code simulps/simul2000 (Thurber and Eberhart-Phillips, 1999; Thurber, 1983). We followed the standard procedure for this method, and for details the reader is referenced to several works published and references therein (e.g. Braeuer et al., 2012; Chiarabba et al., 2009; Dias et al., 2007; Haslinger et al., 1999; Husen et al., 2002; Kissling et al., 2001; Kohler and EberhartPhillips, 2002).

\subsection{0 models}

202 The first step in the inversion was to derive a new 1D model to be used as initial input model 203 for the 3D inversion, using the VELEST code (Kissling et al., 1994). Considering the geological 204 heterogeneity in mainland Portugal and the seismicity distribution, the two north and south 205 selected datasets were used to first derive a specific 1D model for each of the regions, 206 followed by a final inversion using the complete dataset to derive the final "best" or 207 minimum 1D model (cf. Fig.5).

All information regarding 1D or 2D models available for Portugal were used for input, namely those used in routine earthquake location at IPMA's (Custódio et al., 2016) or derived on

211 studies previously conducted in Portugal, either from earthquake based analysis (Carrilho et 212 al., 2004; Díaz et al., 2009; Dündar et al., 2016) or deep-seismic soundings experiments (Díaz 213 et al., 1993b; Díaz and Gallart, 2009; Gonzalez et al., 1996; Matias, 1996).

215 The initial Vp/Vs ratio value, used both during the 1D inversion and as the initial reference 216 value in the 3D inversion, was 1.74 and was determined by a Wadatti diagram (cf. Fig.S3 in 217 supplementary material). 
219 The main differences during the modeling between the two datasets were due to the 220 shallower portion of the models, the southern requiring a slower upper crust. The lower 221 crust present also some sharp differences but these can partially be attributed to instabilities

222 in the solutions due to the exclusion of the more distant arrivals.

224 The initial RMS of the whole dataset hypocentral parameters was $0.539 \mathrm{~s}$, and following the 225 picks corrections and with the final 1D model, the RMS dropped to $0.251 \mathrm{~s}$, a reduction of $22647 \%$. This final RMS value is dominated by the more numerous southern dataset,, the 227 northern events having generally slightly higher RMS values (cf. Fig.S4 and S5 in 228 supplementary material).

\subsection{D model parameterization}

232 The crustal volume under study was parameterized with the grid of Fig.3, the position of the 233 nodes conditioned by the distribution of ray-density and other indicators, like the DWS and 234 RDE (Kissling et al., 2001).

In the south and extreme north of Portugal, ray-density is relatively uniform, but between 39.5 o and 41.5 oN there is a gap due to low seismicity rate and small number of seismic stations; part of the difficulties faced during the 1D and 3D inversion were due to this hiatus in ray coverage and the connection between the two northern and southern blocks. The final grid-nodes disposition, though far from ideal and inducing a north-south stretching in images

241 in the mid-sectors of the model, was the only parameterization that allowed a continuous model with satisfactory resolution.

244 Besides the displayed horizontal positions, similar planes of grid-nodes were positioned at depths of $-1,1,4,8,12,16,20,24$ and $30 \mathrm{~km}$; the external boundary planes placed $500 \mathrm{~km}$

246 for each side of the center of the grid (not shown it the following figures). The already 247 referred figures S1 and S2 in the supplementary material present the ray-density distribution that controlled the grid-nodes set-up. 
250 The total number of nodes is 2640 , corresponding to a total of $5280 \mathrm{Vp}$ and Vp/Vs model 251 parameters which, together with the four hypocenter parameters of the 2640 events, result 252 in a total of 10560 unknowns. For the total of 49227 phase readings this leads to an overall 253 over-determination factor of 4.04.

The damping factors for the $\mathrm{Vp}$ and $\mathrm{Vp} / \mathrm{Vs}$ inversions were determined by trade-off curves

256 (Eberhart-Phillips, 1986). The selected values were 300 for the $\mathrm{Vp}$ and 150 for the $\mathrm{Vp} / \mathrm{Vs}$ ratio 257 inversions (Fig.S6 in supplementary material). Other critical parameters selected on a trial258 and-error basis were the overall phase weights, with a linear RMS reduction from 0.2 to $0.7 \mathrm{~s}$ 259 and cut-off distances, with a linear reduction between 150 and 300 km (according to Fig.4 260 and Fig. S4).

262 The final run simultaneously inverting for $V p, V p / V s$ and earthquake location required 4 263 iterations. The final model, presented in $\S 5$, allowed an overall RMS reduction of 58\% 264 relatively to the final 1D for the hypocentral parameters, dropping to $0.146 \mathrm{~s}$ (cf. Fig.S5 in 265 supplementary material).

Considering the strict criteria applied in the selection of the events, the epicentral 268 distribution obtained from the 3D modeling does not change significantly the sketch resulting from the $1 \mathrm{D}$ modeling. The major observable differences being on the depth distribution. While the 1D model tends to have a more homogeneous depth distribution of 271 hypocenters, with more events located at deeper crustal depths, the 3D model has a 272 tendency to cluster the hypocenters in two main ranges: a shallow upper crustal "layer", with 273 events having depths smaller than $4 \mathrm{~km}$, and an intermediate crustal "layer" where the 274 majority of the hypocenters tend to occur between 7 and $20 \mathrm{~km}$ depths, very few events 275 being located at the lower crustal levels (cf. Fig. S7 in supplementary material).

\subsection{Model Resolution assessment}

279 The evaluation of the quality of the final 3D model was made both by the usage of synthetic 280 tests, like checkerboard anomalies, and by the analysis of several numerical variables. As 
281 several authors pointed out (Husen et al., 2003; Kissling et al., 2001; Rawlinson and 282 Spakman, 2016), the resolution assessment should not be based on a single test or indicator.

284 Figure 6 shows the result of the checkerboard sensitivity test output for both the $\mathrm{Vp}$ and $285 \mathrm{Vp} / \mathrm{Vs}$ models. A synthetic spike-sensitivity test was also performed, not shown since it gave 286 roughly the same indications but with lesser quality. Figures S8 and S9 in supplementary 287 material show the output of the numerical resolution variables calculated from the inversion 288 (Foulger et al., 1995; Toomey and Foulger, 1989), the diagonal of the resolution matrix (RDE) 289 and the Spread Function (SF) distribution. These should be analyzed together with the KHIT 290 and DWS distribution of figures S1 and S2.

Both Fig. 6 and figures S1-S2 and S8-S9 show that the resolution in the upper crustal layers is good, with a few unresolved nodes at the borders of the models, particularly those located at the western edges. Excluding the stretching of the features between latitudes 39 to 41ㅇN, no significant smearing is observed for layers $Z=1$ to $12 \mathrm{~km}$; between 12 and $16 \mathrm{~km}$ the resolution starts to decrease with sectors presenting significant smearing or failure to retrieve the initial anomalies.

To prevent ill-resolved areas to affect the geological interpretation, it is prudent to find a way of removing unresolved nodes from the graphical representation of the model. The several figures previously presented, with the numerical resolution parameters and the synthetic tests, do not allow to clearly define the limit between well and poorly-resolved areas. In order to find a cut-off value for the representation of the resolved nodes of the final 3D model, we followed the approach of Dias et al. (2007): plots of the DWS and RDE values versus the SF value of all nodes and for both the $V p$ and $V p / V s$ models, to define a threshold 307 SF value for resolved nodes (cf. Fig. 7). The higher the SF for a given node, the greater the 308 contribution from nearby nodes and the smaller the reliability of the solution obtained for that node. The graphics in Fig.7 show that the resolution for both models can be considered satisfactory for $\mathrm{SF}<1.5$, and for $\mathrm{SF}>2.5-3.0$ the resolution is null, the SF cut-off value being

311 located in between. The comparison between the output of the several synthetic tests 
312 performed and the distribution of the DWS, RDE, and SF planes, points to a cut-off value of

3132.8 for the $\mathrm{Vp}$ and 3.0 for the $\mathrm{Vp} / \mathrm{Vs}$ models.

\section{Results}

317 The final $V p$ and $V p / V s$ models are presented in figures 8 and 9 . In both cases all node 318 volumes for which their SF is above the respective selected threshold are masked. Each represented horizontal or vertical plane include all relocated earthquakes localized in a slice volume centered in the plane, the thickness of the slice determined by the closest nodes interspacing, usually $20 \mathrm{~km}$ for vertical planes (10 km for each side) and $4 \mathrm{~km}$ for horizontal planes ( $2 \mathrm{~km}$ for each up-down side). Figure 8 presents both models plotted on horizontal planes, coincident with the horizontal grid XY planes, whereas Figure 9 represents them along selected vertical profiles, either coincident with the XZ or YZ planes (Fig.9a) or along oblique SW-NE or NW-SE profiles (Fig.9b). The horizontal planes are useful mainly to evaluate the lateral horizontal extension of the features, and in particular their correlation with surface geology, whereas the vertical planes are more important to define the vertical extension of the main features and their contrasts. The resolution of the nodes decrease rapidly for depths greater than $20 \mathrm{~km}$, with very few of the nodes of the horizontal plane $\mathrm{Z}=30 \mathrm{~km}$ having good resolution; therefore conditioning the depth representation of the models to the upper-middle crust.

333 As the 1D models already hinted, the analysis of the horizontal maps of Fig. 8 show that the seismic velocities of the upper crust are on average higher in the north than in the south, the south showing much more heterogeneity. Previous work using ambient-noise tomography

336 (Silveira et al., 2013) already showed a tendency of higher group-velocities associated to the 337 north of Portugal and the strong effect associated with the Iberian margin. The vertical 338 distribution of $\mathrm{Vp}$ values of the final 3D model fluctuates between 5.7-6.1 km/s in the upper $3395 \mathrm{~km}$, between $5.8-6.2 \mathrm{~km} / \mathrm{s}$ in the range $5-10 \mathrm{~km}, 6.0-6.3 \mathrm{~km} / \mathrm{s}$ in the range $10-15 \mathrm{~km}, 6.2-6.5$ $340 \mathrm{~km} / \mathrm{s}$ in the range $15-20 \mathrm{~km}$ and $6.4-6.9 \mathrm{~km} / \mathrm{s}$ in the range $20-25 \mathrm{~km}$, values which are 341 consistent with previous studies carried in the Iberian Massif in particular DSS campaigns 342 (Afilhado et al., 2008; Díaz et al., 1993b; Díaz and Gallart, 2009; Ehsan et al., 2015; Flecha et 
343 al., 2009; Gonzalez et al., 1996; Matias, 1996; Palomeras et al., 2011; Poyatos et al., 2012;

344 Simancas et al., 2004; Téllez et al., 1993; Victor et al., 1980). For depths greater than $25 \mathrm{~km}$

345 the model resolution drops dramatically, with only a couple of isolated nodes having a 346 minimum SF value above the defined threshold; therefore, no unequivocal discussion related 347 with Moho depths is possible.

349 Considering the grid design, namely the uneven spacing between nodes in N-S/Y-direction, 350 coupled with the surface geology, two distinct areas emerge from the obtained tomograms: 351 a northern sector coincident with center-north Portugal and southern Galicia, and a southern 352 sector stretching from the Lower Tagus-Valley until the Algarve, the limit between the two sectors being located around 39.5ㅇN.

\subsection{Northern Portugal and Southern Galicia}

This sector, encompassing the region roughly north of $39.5 \mathrm{~N}, \mathrm{Y}>60 \mathrm{~km}$ in Fig.3b, includes the Galicia-Trás-os-Montes Zones (GTMZ), the largest part of the Centro-Iberia Zone (CIZ) and the northern part of the Lusitanian Basin (LB) (cf. Fig.2).

Both figures 8 and 9 show that the seismic structure beneath the $\mathrm{CIZ}$ is relatively smooth and homogeneous, the velocities and $\mathrm{Vp} / \mathrm{Vs}$ ratio varying smoothly when compared with the structure visible to the south beneath the OMZ and SPZ. Such smoothness maybe partially the result of the wider grid spacing, but is nonetheless consistent with previous studies in particular DSS campaigns carried in the area (Díaz et al., 1993b; Díaz and Gallart, 2009; Matias, 1996; Téllez et al., 1993).

In the northern sector, the greatest model heterogeneities are observed in the area around the Spanish-Portuguese border above 41ㅇN, corresponding to the regions of Minho and Trásos-Montes in Portugal and southern Galicia in Spain, roughly coincident with the GTMZ

371 positioning (cf.Fig. 2). The $\mathrm{Vp}$ values tend to be relatively low $(<6.0 \mathrm{~km} / \mathrm{s}$ ) when compared with those from areas slightly to south, $\sim 0.2 \mathrm{~km} / \mathrm{s}$ smaller, with exception of two high $\mathrm{Vp}$ anomalies $(\sim 6.2 \mathrm{~km} / \mathrm{s})$ roughly at the same latitude of $\sim 42.29 \mathrm{~N}(\mathrm{Y}=380)$. The seismicity 
374 distribution in the area seems to be controlled by the position of these two high Vp spots, 375 and confined by the relatively lower $V p$ areas. The general lower $V p$ area seems to be 376 confined to the uppermost levels of the crust, vanishing at depths of $\sim 8 \mathrm{~km}$ (cf. Fig. 8 and 377 profiles $A-A^{\prime}, G_{-} G^{\prime}$ in Fig.9a and $\mathrm{H}^{-H^{\prime}}$ and $\mathrm{I}-\mathrm{I}^{\prime}$ in Fig.9b). One of the high $\mathrm{Vp}$ anomalies is 378 located near the coast, south of the "Rias Bajas" ( 8.8W), whereas the other is located to 379 the east roughly coincident with the mountain range of the Ourense Central Massif ( 7.6W).

380 The western high $\mathrm{Vp}$ anomaly seems to be detached in depth, with a reduction in $\mathrm{Vp}$ that can 381 be perceived at $8 \mathrm{~km}$ depth (cf. profile B-B' in Fig.9) whereas the eastern anomaly seems to 382 extend to the deeper crust (cf. profile $A-A^{\prime}$ in Fig.9). At the shallow layers, the $V p / V s$ ratio 383 across the area show some fluctuations around 1.72 , but it is at mid-crustal levels that 384 greater variations can be observed and mainly beneath the areas with more seismicity (cf. 385 levels 12 to $20 \mathrm{~km}$ depth in Fig.8, and northern profiles in Fig.9). A localized very low $\mathrm{Vp}$ 386 anomaly, $\sim 5.7 \mathrm{~km} / \mathrm{s}$, is observable at $41.5 \circ \mathrm{N}$ and $7.7 \mathrm{oW}$ in the plane $\mathrm{Z}=1 \mathrm{~km}$ in Fig.8, and apparently extending up to $8 \mathrm{~km}$ depth where its shape seems to slightly increase and assume a SSW-NNE orientation.

The general horizontal outline of the referred anomalies disposition in this area (cf. Fig.8), mainly at the shallow layers $Z=1 \mathrm{~km}$ and $4 \mathrm{~km}$, suggest a NE-SW alignment that can be correlated with the orientation of the GTMZ and of the Ibero-Armorican Arc (cf. Fig.2a).

The area between 39.5을 $419 \mathrm{~N}$ presents more homogenous $\mathrm{Vp}$ values, in particular in the area corresponding to the $\mathrm{CIZ}$, but between depths of 8 to $20 \mathrm{~km}$ there is evidence of a central region with high $V p$ values $(\sim 6.4 \mathrm{~km} / \mathrm{s})$ that seem to be limited between two major tectonic faults, the PTFA and the MVB (cf. Fig.2b), and which has not been previously reported. The ILIHA DSS profiles (Díaz et al., 1993b; Matias, 1996) reported an homogenous crustal structure with no significant lateral variations on the $\mathrm{Vp}$ structure with a basically flat 400 Moho; on the other hand, recent PRF studies (Dündar et al., 2016; Mancilla and Diaz, 2015) 401 point to some variation in the Moho topography in the area of the Spanish-Portuguese border, which may be a consequence of this $\mathrm{Vp}$ variations.

404 The Penacova-Régua-Verin (PRV) and the Manteigas-Vilariça-Bragança (MVB) fault systems are some of the major structures of the northern Portugal, in this case extending also into 
southern Galicia, their signature being clear in the model, the last in spite being located on

407 its eastern border. Both the horizontal planes of Fig. 8 and profile A-A' and H-H' in Fig.9, show 408 a transition between a high $\mathrm{Vp}$ area in the west to a low $\mathrm{Vp}$ area, the limit roughly coincident 409 with the position of this fault system; the $\mathrm{Vp} / \mathrm{Vs}$ also presents a similar pattern, though less marked, with a tendency of higher $\mathrm{Vp} / \mathrm{Vs}$ values east of the fault.

412 Along the western part of the model, the transition between the $\mathrm{CIZ}$ and the Lusitanian Basin 413 LB is well marked, both on the horizontal planes of the model (Fig.8) and in particular on the 414 vertical W-E profile B-B' and SW-NE profile I-I' of Fig.9ab. This transition is marked by a sharp 415 lateral transition to the western direction in $\mathrm{Vp}$ and $\mathrm{Vp} / \mathrm{Vs}$ values, with a reduction $\sim 0.2 \mathrm{~km} / \mathrm{s}$ 416 of $V p$ and strong alternation of $V p / V s$ differences $>0.4$, the anomalies distribution suggesting 417 a contact boundary roughly with a N-S direction. This boundary is consistent with the 418 position of the Porto-Tomar-Ferreira do Alentejo shear zone, PTFA in Fig.2b, the contact 419 between the Variscan structures of the $\mathrm{ClZ}$ and the Cenomesozoic structures of the 420 Lusitanian Basin LB (Chaminé et al., 2003; Pais et al., 2012). The shallow layers of profile B-B' 421 seem to define three distinct low $\mathrm{Vp}$ anomalies, whose separation appear to be roughly 422 located at longitudes $8.5 \mathrm{oW}$ and $8.0 \mathrm{oW}$ and coincident with the position of some of the fault 423 systems observed in Fig.2b, the NCA and the crossing of the Arr-PTFA faults. The vertical 424 disposition in depth of the anomalies suggest a fault system extending into the lower crust, dipping 70 을 to the $\mathrm{W}$.

427 Regarding the Vp/Vs ratio, the map present some heterogeneity especially in the upper crust, with values varying between 1.62 and 1.76; for the deeper layers, the heterogeneity reduces somewhat but with a tendency of increasing the average values for values above 1.72 . This is 430 in contrast with the results of the study by Dündar et al. (2016), where the average crustal $431 \mathrm{Vp} / \mathrm{Vs}$ ratio is usually below 1.75 with the exception of some small anomalies located near 432 the coast. Unlike the $\mathrm{Vp}$ anomalies horizontal pattern on Fig.8, the Vp/Vs tends to present an 433 image of N-S alignment of the anomalies, even on the northernmost area where it should be 434 less conditioned by the grid design; the analysis of the $\mathrm{Vp} / \mathrm{Vs}$ pattern is less obvious than the 435 corresponding $\mathrm{Vp}$, with exception of the clear definition of the margin transition between 436 the LB and the $\mathrm{CIZ}$ well defined in Fig.8. Since the major fault systems in this area have an 437 orientation between N-S and NNE-SSW, and considering that the Vp/Vs ratio is more sensible 
438 to lithological variations and in particular fault creep effects (e.g. Eberhart-Phillips and 439 Michael, 1998), this orientation is probably a result of the fault systems signature.

\subsection{Southern Portugal (Lower Tagus Valley, Alentejo and Algarve regions)}

443 The region south of $39.5 \mathrm{oN}$ ( $\mathrm{Y} \leq 60 \mathrm{~km}$ in Fig.3b), includes the southernmost part of the

444 Lusitanian Basin LB, the Cenozoic Lower-Tagus-Sado Basin LTSB which includes the Lower445 Tagus Valley LTV, the Ossa-Morena OMZ and South-Portuguese Zones SPZ, the contact region $\mathrm{CIZ-OMZ}$ and the Algarve Basin AB (cf. Fig.2b).

Due to higher density of information, this region corresponds to the area better sampled by seismic rays, a consequence of the higher seismicity rate and denser seismic permanent network, the closer node disposition allowing a better definition of the model features in terms of spatial size. It is the most geologically heterogeneous region of the study area, which is well marked on the horizontal planes of Fig.8, in particular the shallower ones. To some extent, such heterogeneity was already expected considering that this region comprises the $\mathrm{OMZ}$, the most heterogeneous unit of the Iberian Massif in Portugal, wellmarked on the upper layers of the model on Fig.8.

The contrast with the fairly smooth area of the $\mathrm{ClZ}$ is evident, although the transition position suggested by the model is not completely coincident with the defined $\mathrm{CIZ}-\mathrm{OMZ}$ boundary, the Tomar-Badajoz-Córdoba shear zone whose position lies slightly to the NE (TBC in Fig.2b), its expression in the model much weaker. In both the $\mathrm{Vp}$ and $\mathrm{Vp} / \mathrm{Vs}$ models there is a clear contrast roughly coincident with the direction of the seismic alignment visible at $\sim 38.2^{\circ} \mathrm{N}$, located in the Ciborro-Arraiolos region (Cib in Fig.2b), with the TBC lying $\sim 60 \mathrm{~km}$ to 463 NE being marked by a smaller contrast. East of the Cib alignment and possessing approximately the same orientation, the main structure visible on the field is the Serra da Ossa OA fault, and the couple Cib-SO orientation apparently correspond to an important Vp contrast in the Vp model. On the vertical profiles of Fig.9, a clear sub-vertical Vp contrast associated with the Cib-SOis observed in the upper 10km at longitude 7.5 oW in $\mathrm{C}^{-} \mathrm{C}^{\prime}$, at 468 latitude $\sim 38.9$ - N in G-G' and $\sim 200 \mathrm{~km}$ in $\mathrm{K}-\mathrm{K}^{\prime}$. The area between the Cib-SO alignment and 
$\mathrm{OMZ}-\mathrm{ClZ}$ boundary is marked by a low $\mathrm{Vp}$ volume observable roughly at latitude 39.3 o $\mathrm{N}$ in G-G' and $\sim 240 \mathrm{~km}$ in $\mathrm{K}-\mathrm{K}^{\prime}$ marked by a gradually increase in $\mathrm{Vp}$ values. The TBC is much

471 clearer in the Vp/Vs signature, with the area confined by the Cib and the TBC being marked 472 by high $\mathrm{Vp} / \mathrm{Vs}>1.7$. The absence of the TBC on the upper level of the model $(\mathrm{Z}=1 \mathrm{~km})$ may be 473 due to an effect associated with the decrease in the sampling of the crustal volume, since to 474 the NE of the Cib alignment the seismicity rate drops dramatically and thus the inter-node 475 distance increase (Poyatos et al., 2012).

477 To the west, the transition between the LB and the $\mathrm{OMZ}$ is clear, the separation being well 478 marked by a very low Vp $(<5.8 \mathrm{~km} / \mathrm{s})$ area roughly coincident with the LTV (cf. Fig.8). Both 479 Fig.8 and profiles C-C' and J-J' show that this low Vp anomaly is limited to the crust's upper $48010 \mathrm{~km}$, more probably to the upper $5 \mathrm{~km}$ an effect of the thick sedimentary coverage of the 481 LTSB basin in this area. For depths greater than $10 \mathrm{~km}$, no significant lateral transition is observed either on the $\mathrm{Vp}$ or $\mathrm{Vp} / \mathrm{Vs}$ structure nor any significant seismicity alignment is observed in the area.

Due to the sediment cover of the LTSB, there is some discussion on whether the OMZ or the SPZ stretches until the margin, a suggestion made by ambient noise studies (Silveira et al., 487 2013). The area between the coast line and the $\mathrm{OMZ}$, roughly between latitudes 38.--38.59N is characterized by low Vp values on the upper crust, overlying a fast middle-lower crust (cf. 489 profiles D-D' and F-F' in Fig.9a), but it is not clear with which zone are these values akin. In 490 Fig.8 the position, shape and values of the low Vp anomalies seem to suggest an horizontal extension of the low Vp associated with the SPZ-OMZ boundary observed eastward.

493 To the south of the Cib-SO alignment, a globular diffuse seismic cluster can be observed with no clear alignments. The $\mathrm{Vp}$ and $\mathrm{Vp} / \mathrm{Vs}$ anomalies in this area seem to elongate on a WNWESE direction, probably an effect of the Ibero-Armorican Arc (cf. Fig.2a), with some of the stronger anomalies coincident with the globular cluster of earthquakes (cf. Fig.8). This cluster seems to extend in the SW-NE direction, apparently confined to the SE by the Odemira-Avila 498 OA Fault, which itself doesn't seem to correspond to a specific seismic alignment. Profile J-J' (Fig.9b) shows that the seismicity in this area is coincident with high $\mathrm{Vp}$ and high $\mathrm{Vp} / \mathrm{Vs}$ areas, 
500 confined by areas of both low $\mathrm{Vp}$ and $\mathrm{Vp} / \mathrm{Vs}$ and are probably associated with several granitic 501 intrusions in the area.

503 The position of the OA fault and corresponding contact between Paleozoic and Ante504 Ordovician rocks is well marked on the model: in Fig. 8, and within the OMZ, by a high-low $505 \mathrm{Vp}$ transition with the velocity iso-contours roughly parallel to the fault, whereas in Fig.9 it 506 can be perceived at 37.99 $\mathrm{N}$ in profile $\mathrm{G}-\mathrm{G}^{\prime}$ and at $\sim 170 \mathrm{~km}$ in profile J-J'.

At southern $\mathrm{OMZ}$ the $\mathrm{Vp}$ values are generally lower than at the northern part, enhancing the 509 transition to the SPZ where the velocity values are higher. The SPZ-OMZ transition is marked 510 in Fig. 8 mainly at planes above $12 \mathrm{~km}$, with the $\mathrm{Vp}$ anomalies contours roughly aligned on a 511 WNW-SSE direction; in profiles F-F' and G-G' of Fig.9a this contact is clear at latitudes of $51238.19 \mathrm{~N}$ and $37.8 \mathrm{oN}$ respectively. On profile $\mathrm{K}-\mathrm{K}^{\prime}$ of Fig.9b, roughly perpendicular to the 513 contact, this contact is located at $\sim 100 \mathrm{~km}$ and show also that the low $\mathrm{Vp}$ area associated with 514 southern OMZ "bends" to NE suggesting that the SPZ extends beneath the OMZ, as already 515 pointed by the IBERSEIS results (Simancas, 2003). As for the Vp/Vs anomalies the SPZ-OMZ 516 do not have a clear signature, except for the fact that the general WNW-ESE shape of the 517 anomalies observed in Fig.8 inside the OMZ seems to be replaced by less defined orientation 518 is the SPZ. The overall signature of the SPZ-OMZ in Fig.8 is thus perturbed by the 519 superposition of several features, the contact itself, the OA fault and the southern branch of 520 the Lower-Tagus-Sado basin (LTSB).

522 The South-Portuguese Zone (ZOM) as long been assumed as relatively homogenous (cf. 523 Fig.2), with the eventual exception of the area close to the SPZ-OMZ contact to the 524 northeast, along the Iberian Pyrite Belt, and the southwestern most tip near the Cape of 525 Saint Vicente. The obtained $V p$ and $V p / V s$ models points to a more complex structure 526 instead.

528 The most striking signature in the models is the apparent W-E segmentation of the SPZ, with 529 a general increase in Vp values from west to east visible in practically all planes of Fig.8 over 530 the resolved areas, and in profile E-E' of Fig.9a. The Vp/Vs also present the same tendency, 531 albeit less clear. The iso-contours of the model suggest a roughly N-S limit not previously 
reported, butthe fact that there is a seismicity alignment roughly coincident with the W-E

533 variation position in the model suggest that it reflects the presence of a major rheological

534 contact between two distinct blocks.

536 While the "fast bloc" occupies all the SPZ area east of this "contact", the "slow bloc" seems 537 to be also limited by the OA fault, since the SPZ that outcrops near the coast north of the OA 538 fault presents higherVp values akin with the eastern ones.

540 The Monchique Massif (M), corresponding to a Mesozoic essentially syenitic massif intrusion, 541 presents a strong signature in the models and also a high seismicity rate cluster, centered on 542 the Massif. Profiles F-F' and $\mathrm{K}^{\prime} \mathrm{K}^{\prime}$ in Fig.9 both have a cross-section of the Massif: in the 543 upper $5 \mathrm{~km}$, a high $\mathrm{Vp}$ anomaly with scarce seismicity is observed, which corresponds 544 probably to the main sienitic body of the Massif, lying above a low Vp anomaly where the majority of the earthquakes are located. Although both vertical profiles seem to suggest

546 high/low Vp/Vs coincident with the referred $\mathrm{Vp}$ anomalies, the $\mathrm{Vp} / \mathrm{Vs}$ planes of Fig.8 point to 547 a greater variability of the $\mathrm{Vp} / \mathrm{Vs}$ values.

549 To the SW of the Massif, there is evidence of significant anomalies in the Vp and Vp/Vs ratios. 550 Although this sector is located on the border of the model, in an area with poor ray551 coverage, the suggestion of great heterogeneity is supported by several studies (Dündar et 552 al., 2016; El Moudnib et al., 2015; Gonzalez-Fernandez et al., 2001; González et al., 1996; 553 Matias, 1996; Rocha et al., 2010; Salah, 2013).

The Monchique Massif, together with the Sintra (S) and Sines (Si) massifs (cf. Fig.2b), composes an alignment of three similar intrusive granitic/syenitic massifs. Unlike Monchique, the ray-coverage of this study do not allow a good sampling of Sintra and Sines, with Sintra located outside the covered area; as for Sines, it lies in the western limit of the model and the shallow high $V p$ anomaly located in the westernmost side of profile D-D' in Fig.9a, at $9 \circ \mathrm{W}$, is probably the signature of the Si massif.

562 Finally, there is the low $\mathrm{Vp}$ and high $\mathrm{Vp} / \mathrm{vs}$ signal at the southernmost part of the model, roughly around $8 \mathrm{oW}$, that is probably the signal of the Mesocenozoic rocks of the Algarve 
564 Basin (AB). On average, the $V p$ values on the $A B$ tend to be slightly than those of the $L B$ but 565 being located on the limit of the model, with only a few nodes sampling the area, do not 566 allow any further conclusion.

\subsection{Seismicity distribution and active faults}

569

To better access the seismicity distribution and eventual relation between alignments and

571 seismic active faults, we decided to add additional events from the original dataset and 572 relocated them with the new 3D model. To keep some confidence in the hypocentral 573 solution, only events recorded at least by four stations and with good azimuthal coverage 574 (GAP<180) were selected. As result 3735 additional events were obtained and relocated, 575 their epicenters plotted in Figure 10, together with the 2640 used in the inversion process. To 576 discriminate between the two datasets, the events used in the inversion have a symbol 577 slightly bigger and are superimposed over the additional events. The events are plotted over 578 three different depth ranges, defined according to the logic used in Fig. 8: shallow events 579 located in the top of the crust above $2.5 \mathrm{~km}$ (the upper plane $\mathrm{Z}=1 \mathrm{~km}$ ), mid-crustal events 580 located 2.5-14 km depths (planes $Z=4,8,12 \mathrm{~km}$ ) and deep crustal events for all deeper than $58114 \mathrm{~km}$ (planes $\mathrm{Z}=16,20,24 \mathrm{~km}$ ).

583 The analysis of Fig.10 shows that the shallower seismicity $(Z \leq 2.5 \mathrm{~km}$, Fig.10a) does not define 584 clear alignments with the exception of the one associated with the Cib fault. The clusters 585 around Lugo, in the north in Galicia $(\sim 42.8 \mathrm{~N})$ ), in most of the Alentejo area between 38N 586 and $38.8 \mathrm{~N}$ and around the Monchique Massif ( $37.8 \mathrm{~N})$, are already defined.

588 The intermediate depths (Fig.10b), corresponding to mid-crustal seismicity is the one that 589 defines more clearly the majority of the identified anomalies, namely those associated with 590 the PTFA shear zone, PRF and MVB fault systems and the other several faults/alignments 591 (CBo, Po, NCA, CPM, Arr, Cib, MST).In the northern sector the seismicity is distributed, on a 592 first analysis, along some of the well-defined fault systems of Fig.2b: the Porto-Tomar593 Ferreira do Alentejo (PTFA) shear zone, the Penacova-Régua-Verin fault zone (PRV) and the 
594 Manteigas-Vilariça-Bragança Fault Zone (MVB), whereas a diffuse seismicity is disseminated

595 in the Minho, and Galicia mainly included in the Galicia-Trás-os-Montes Zone (GTMZ).

596

597 On the deeper crustal level (Fig.10c), there is still some seismicity, with some alignments still 598 clear whereas others fade. Seismicity alignments still apparent are those along the PTFA 599 shear zone, the MVB fault system and the NCA, CPM and MST faults. The seismicity over the 600 Cib no longer defines a clear alignment, with the activity reduced to a cluster on the eastern 601 segment of the alignment. The seismicity cluster around the Monchique Massif is still very 602 active.

603

604 The association of all this seismicity with the referred fault systems can be seen in Fig.10d. 605 The maps of Fig.10 show clearly that the majority of the hypocenters is confined to the 606 upper-middle crust, with only a few structures extending into the base of the crust.

607

608 A note should be added to a the cluster that now appears in Fig.10 in SE Alentejo, around $60937.69 \mathrm{~N}$ and $7.9 \circ \mathrm{W}$ and previously hardly distinguishable in figures 8 and 9. This cluster 610 position is roughly coincident with the area of the Neves-Corvo mine, a massive sulphide 611 deposit with significant amounts of copper and zinc. The majority of the events located at 612 deeper crustal layers correspond to the additional less-constrained ones, most of the well613 constrained events used in the inversion having shallow locations; thus, this cluster may 614 reflect the mining activity with explosion, having low magnitudes $(M<2.0)$ being mistaken by 615 small earthquakes although the deeper ones $(>15 \mathrm{~km})$ can hardly be attributed to that.

\section{6. Discussion}

619 In the area of the Galicia-Tras-os-Montes GTMZ region, the fact that low Vp values are 620 observed in the shallow layers of the model is consistent with hypothesis of being composed 621 by a pile of allochthonous thrust sheets, overlying the autochthonous Central Iberian Zone $622 \mathrm{CIZ}$ The diffuse seismicity of the GTMZ region is not yet completed clarified(Martín-González, 623 2009; Martínez-Díaz et al., 2006; Vázquez et al., 2008), with some authors suggesting that it 624 could be trigged by some magmatic diapirs (Boillot et al., 1980) in depth associated with an 
625 intense hydrothermal and magmatic pneumatolytic activity. The activity could also be 626 intensified by the heritage of some of the active faults that controlled the subsidence of the

627 "Rias Bajas" and endorse the indented shape of the littoral border. The existence of several 628 medium temperature hydrothermal springs, some of them with a low to medium geothermal 629 values and mineralizations (Lourenço and Cruz, 2006; Lourenço, 1998), also corroborate 630 these considerations and can explain the observed low Vp associated with the seismicity and 631 the variations in the $\mathrm{Vp} / \mathrm{Vs}$ ratio in depth.

633 The subvertical PTFA shear zone (Chaminé et al., 2003), with N15E to 634 N30Wstrike,concentrates the large majority of events south of GTMZ. It is a major accident 635 of the Iberian Variscan chain that some authors relate with a Cadomian mega structure - a 636 transform fault, reactivated during Variscan orogeny (Ribeiro et al., 2009) and dated to have 637 acted at ca. 208 Ma ago (Gutiérrez-Alonso et al., 2015; Linnemann et al., 2008). Despite the seismic 638 activity along its trace and associated with its northern termination, it does not present 639 significant signatures in the $\mathrm{Vp}$ map, only the $\mathrm{Vp} / \mathrm{Vs}$ ratio showing a hint of its presence, and 640 will thus be discussed in the following section.

642 The PRV fault zone is essentially a strike-slip sinistral fault trending N15 to N30E. Its presence 643 is marked by a low-velocity anomaly at the upper crustal levels, roughly at $41.89 \mathrm{~N}$ and $7.6 \div \mathrm{W}$, 644 clearly visible at the $Z<8 \mathrm{~km}$ surfaces(cf. Fig.8) and in profiles A-A' and E-E' (cf. Fig.9), and $645 \mathrm{Vp} / \mathrm{Vs}$ values slightly lower than 1.7.Displays left kinematic movement during the Cenozoic 646 (locally with a thrust components to $\mathrm{W}$ ) of over $250 \mathrm{~km}$ length, and is an important Variscan 647 inherited structure affecting more recent Quaternary sediments(Cabral, 1989; De Vicente et 648 al., 2011).It has a strong instrumental seismicity record and is associated with various 649 sources of hydrothermal features of hot water (Lourenço and Cruz, 2006; Lourenço, 1998), 650 locally with mantle signature, i.e., Chaves high enthalpy spring, thus explaining the low $\mathrm{Vp}$ 651 and $\mathrm{Vp} / \mathrm{Vs}$ present in the model.

653 As described in §5.1, the Centro-Iberian Zone is marked by relatively uniform high Vp values, 654 with the highest values being observed at mid-crustal layers and roughly limited between the 655 PTFA and MVB faults, whereas the $\mathrm{Vp} / \mathrm{Vs}$ has smooth variations usually above 1.72 and 656 mainly in the shallower crust. The apparent N-S orientation of this high $\mathrm{Vp}$ region do not 
appear to be completely coincident with that of the faults, which may be due to an effect

658 induced by the model grid, or with the main orientation of the Variscan structures;

659 nonetheless, this anomaly may be reflecting different rheologic areas within the $\mathrm{ClZ}$ crust

660 (e.g. between Granites and Schist-Greywacke complexes) that somehow influenced the tardi661 variscan development of these set of faults.

663 The MVB fault system corresponds to a discrete left lateral shear zone, with an NNE-SSW 664 (N10E to N35E) direction, with an estimated length of $230 \mathrm{~km}$ and affecting the Variscan 665 crystalline basement. In the central segment of the Vilariça basin reaches the maximum 666 value of $9 \mathrm{~km}$ on left lateral component(Cabral, 1989), with some authors suggesting to be 667 the final result of several handling stages from Variscan orogeny to the present (late 668 Quaternary)(Cabral, 1995; Neves et al., 2015; Ribeiro et al., 1990; Rockwell et al., 2009). 669 From them at least $1 \mathrm{~km}$ is ascribed as Quaternary Pliocene tectonic events. The Plio670 Quaternary activity of the fault is evident with regional geomorphologic expression and the 671 presence of sediments affected (locally with left lateral and thrust components, Cabral, 1995; 672 Neves et al., 2015). The geomorphological criteria shows several indicators of Quaternary 673 activity in this fault/shear zone that attest the left lateral component: scarps well outlined 674 and rectilinear steps, compressional structures, the significant deflection to the left of Douro 675 river and some small steps of river terraces (Cabral, 1995; Rockwell et al., 2009).

677 As stated above, the transition defined by the MVB fault zone of two volumes within the 678 crust with different $\mathrm{Vp}$ values may explain the thinner crustal thickness values obtained from 679 receiver functions studies for stations located in the area (Dündar et al., 2016; Mancilla and 680 Diaz, 2015).

682 The central area of Portugal, between latitudes of $399 \mathrm{~N}$ and $41 \mathrm{~N} \mathrm{~N}$, corresponds to the 683 volume less well sampled, due to the reduced number of events and stations and 684 consequently with the lowest ray-density. The relatively smoothness is hence probably 685 partially due to the grid geometry, resulting in N-S elongated anomalies both in the $\mathrm{Vp}$ and $686 \mathrm{Vp} /$ Vs ratio. 
688 As previously referred, the PTFA shear zone is one of the main tectonic features of Portugal. 689 It's a roughly N-S oriented contact marking a subvertical tectonic border with uplift of the 690 eastern bloc in a dextral regime), having a sharp signature on the northern part of the model 691 (cf. Fig.8 and profiles A-A' and J-J' in Fig.9). It is a complex and deep shear zone, in some ranges strongly branched (see position of profile B-B' in Fig.9a) and materialized an ancient

693 suture with a long history but it is recognized that is still very active as shown by the current 694 seismicity.

695

696 From the juncture with the Tomar-Badajoz-Córdoba shear zone, this fault system extends 697 south although there is some discussion regarding its extension because it is partially 698 covered by the Cenozoic sediments of the Tagus and Sado Basins, the LTSB in Fig2.b (Pais et 699 al., 2012). Some authors suggest an extension to the SW very close to the coast, roughly 700 defining a thin coastal range (Arenas et al., 2016a; Shelley and Bossière, 2000), a suggestion 701 which does not appear to be supported by our results. The lateral Vp contrasts observed in 702 the area between the $\mathrm{OMZ}$ and the coast line seems to suggest that the PTFA is defining the 703 western limit of the $\mathrm{OMZ}$ and terminating somewhere in the SPZ-OMZ boundary.

704

The low Vp area associated with the Mesozoic rocks of the Lusitanian Basin show also important seismicity, diverting this activity from the PTFA shear zone and distributed along a system of concurrent faults (cf. Figs.2b and 8): the Nazaré-Condeixa-Alvaiázere(NCA), the

708 Candeeiros-Porto de Mós fault (CPM)and the Arrife Fault - Aires-Candeeiros-Montejunto 709 fault system (Arr).These three faults seem to border the low $\mathrm{Vp}$ anomaly block, although the grid does not allow a clear image. While these faults are connected with the rifting stages associated with the creation of the Mesocenozoic domain of the LB(Miranda et al., 2009;

712 Pereira et al., 2016; Ribeiro et al., 1990), they are also inherited from the previous Variscan 713 orogeny geometry, the opening of the Atlantic occurring along the Thetys-Rheic suture zone 714 (Linnemann et al., 2008; Nance et al., 2010; Wilson, 1966).

716 Within the NCA fault system we can consider two branches, to the west the Nazare Fault and 717 to the east the Condeixa-a-Nova - Alvaiázere fault system, the separation being marked by 718 the link to the CPM fault as can be seen by the seismicity distribution (cf. Fig.10d).The Sicó719 Alvaiázere structure is strongly conditioned by Tardi-Variscan accidents that affected the 
720 crystalline basement and whose reactivation influenced the Mesozoic deposition and 721 sedimentary cover (Ribeiro et al., 1979; Rosset et al., 1971). In the eastern edge, some 722 tectonic accidents correspond to roll-overs produced on normal listric fault systems 723 corresponding to an initial extensional regime - the LB (Crispim, 1986; Crispim and Ribeiro, 724 1986). The main massif consists of a set of blocks bordered by faults which sometimes 725 develop syncline and anticline structures. Among these folded structures, some with N70E 726 axial line, there are strike-slip combined structures N30E to N40W (Crispim, 1986; Crispim 727 and Ribeiro, 1986), these orientations consistent with the seismicity alignments and the focal 728 mechanisms observed in the area (cf. Fig.1 and Custódio et al., 2016).

730 The CPM fault system, composed by the W Candeeiros and the Porto de Mós-Rio Maior 731 faults, presents a clear geomorphological expression coincident with the observed seismicity 732 alignment in the LB (cf. Fig.10). With a general orientation N40E to N15E show a variable 733 trend reactivation with horizontal and vertical components according to the stress field 734 direction(Ribeiro et al., 1996). They range from essentially left strike-slip faults to normal 735 and/or reverse faults, as shown by the focal mechanisms in Fig.1, with some of them 736 corresponding to transfer faults between sections with different geometric alignments. The 737 varying rheology contrast in the region, due to the presence of saline diapirs intruded in 738 compact limestones, may help explaining the seismicity in this region (Jeanniot et al., 2016).

740 The Arr fault system is the largest and one of the most typical thrust fault scarps of Portugal 741 (cf. Fig.2b and Fig.10). Located at the east to southeast area of the Estremadura Limestone 742 Massif, the Mezo-Cenozoic Occidental Border, corresponds to a $35 \mathrm{~km}$ fault scarp 743 individualized from an at least 150-180 km fault border Estrela-Seia-Lousã SL (basement 744 Variscan lithologies) and Aires-Candeeiros-Montejunto (Mesozoic cover- essentially 745 limestones and mudstones). The Arrife fault scarp (40-100m high) is a thrust with a variscan 746 heritage that imbricates, generally with a high angle, the Cretaceous and Jurassic limestones 747 on top of Tagus Cenozoic sediments(Pais et al., 2012).

749 To the east, some seismicity alignments can be observed (cf. Fig.10) coincident with the 750 termination of the MVB fault zone and extending to the SW, confined between the SL and 751 the the Cebola-Bogas Cbo fault systems (Ribeiro and Gonçalves, 2013). The signature of 
these fault systems, coupled with superposition with the PTFA fault, clear in profile B-B' of

753 Fig.9b show that this seismicity develops deeply into the Variscan basement. The SL fault is

754 considered an active fault (Custódio et al., 2016, 2015) but our results show that one should 755 consider instead the block confined by the SL and the Cbo fault systems.

757 To the SE, the Ponsul (Po) fault does not present any evident signature in the tomograms, in 758 spite of a few events being present, which may be partially due to the grid design.

Regarding the historic seismicity affecting mainland Portugal, the area of the Lower Tagus Valley (northern part of the LTSB in Fig.2) is one of the more critical due to its high population density. It is associated with several significant historical earthquakes (Cabral et al., 2013, 2004; Carvalho et al., 2008; Custódio et al., 2015), from which a major tectonic fault is deduced, the LTV fault system in Fig.2b. The sediment thickness can reach several km's(Carvalho et al., 2016), making difficult a proper study of the crustal structure. To the NW the LTV is bounded by the uplifted Mesozoic Estremadura region, whereas to NE and SE is bounded by the $\mathrm{ClZ}$ and $\mathrm{OMZ}$. In our model, the LTV fault area is coincident with a lowvelocity area in the upper crust cf. fig.8 and profiles $C_{-} C^{\prime}$ and J-J' in fig.9), consistent with a 4 $\mathrm{km}$ thick basin.

771 The Ciborro fault (Cib)seismicity is aligned along an N70W direction parallel to the Serra de 772 Ossa (SO) fault system (Almeida et al., 2005, 2001). This seismicity presents an unusual 773 diffused seismic activity in the regional context, characterized by not only shallow 774 earthquakes but also deeper events, usually with reduced magnitude $(M<4)$ although some 775 events have been recorded with higher magnitudes $(M>4)$. The seismicity can occur in 776 apparently isolated events, main shock-aftershocks sequences or grouped in temporal 777 and/or spatial swarms (Wachilala, 2015). This kind of seismicity stands out from the typical 778 intraplate standard, like two other regions described in this work, the Galiza-Minho and 779 Monchique regions. The focal mechanisms present some homogeneity of strike-slip dextral 780 type (Wachilala, 2015), with the epicenters bordering to the north the Évora Massif, this 781 accident having a geomorphological expression. 
783 Magnetoteluric soundings carried in the area showed that these $\mathrm{Vp}$ anomalies are coincident 784 with strong resistivity anomalies, in both cases the transition coincident either with the Cib 785 fault or the major alignment of Serra de Ossa SO (Almeida et al., 2005, 2001). However, 786 unlike the Cib alignment, the SO alignment do not present significant seismic activity: this could be related to very different geotectonic domains, to the south related to a high788 pressure crustal signature and to the north a deep sedimentary low-grade Palaeozoic basin.

789 The core of the $\mathrm{OMZ}$, with the associated geological and structural complexity is well 790 represented in observed heterogeneity on obtained tomograms. Such heterogeneity is also 791 observed in the studies conducted in the Spanish side of the OMZ (Ayarza et al., 2010; 792 Carbonell et al., 2004; Palomeras et al., 2011; Simancas et al., 2001, 2003). A strong tectonic 793 inmbrication related with obduction phenomena and high-pressure tectonic events 794 associated with several granitic intrusions in the area (Fonseca et al., 1999) may explain the 795 observed complexity, whereas the concentration of the seismicity may be related with a 796 complex interaction with the Odemira-Ávila OA fault.

797 The OA fault is one of the major tectonic faults recognized in Western Iberia (cf. Fig.2). In 798 spite of being considered active by some authors(Villamor et al., 2012), it does not present 799 any significant events in this study nor instrumental well-constrained seismic activity 800 recorded (Custódio et al., 2015). The OA major fault cuts with a sinistral shear the Alvito801 Viana do Alentejo high-pressure structures located inside the $\mathrm{OMZ}$, an area which shows also 802 some instrumental seismicity related with different rheological properties between blue 803 schists and eclogites and the "Série Negra" black-shales (Fonseca et al., 1999).

804 The low-velocity anomaly observed in Fig.8 $(\mathrm{Z}<16 \mathrm{~km})$, around 7.5W and $38 \mathrm{~N} \mathrm{~N}$, is coincident 805 with the area immediately south of the SPZ-OMZ contact, and extends up to the Albernoa806 Aljustrel-Messejana aligment (AAM in Fig.2b). It is located beneath the "Pulo do Lobo" exotic 807 terrane (Fonseca and Ribeiro, 1993; Vieira Da Silva et al., 2007), and is probably the signal of 808 the mafic rocks associated with the green schists/amphibolitic fácies and some scattered 809 ultramafic outcrops of the Beja-Acebuches ophiolite and the Phyllites and Quartzites 810 outcropping south of the contact.

812 The seismicity within the SPZ present a diffuse pattern to the east, whereas to the west is 813 concentrated either along a roughly NNE-SSW alignment or a cluster around the Monchique814 Massif. The NNE-SSW alignment may be the expression of a branch of the Monchique-Santa 
815 Clara de Sabóia fault (MST in Fig.2b), in spite not being coincident with the position of this

816 fault, and is clearly defined up to 37.8 N where it contacts with OA fault. North of the OA

817 fault there is a suggestion of the continuation of an alignment until Torrão 38.3ㅇN, but some

818 caution must be taken to assume to be the same alignment. In any case, this Monchique-

819 Santa Clara de Sabóia-Torrão alignment has no expression in the existing geological maps;

820 with an N5E to N10E trend, it can only be referred in the field near S. Martinho da Amoreiras

821 - Sabóia area, which corresponds to a sinistral strike-slip discrete shear fault. To the north is

822 covered by the Sado Basin, part of the LTSB in Fig.2b, but should correspond to an active

823 fault system with a clear geomorphologic expression, bordering to the west the Iberian Pyrite

824 Belt region.

825

826 As always the attempt of schematization and geographic systematization difficult some 827 correlation that could be made. Several authors (Shelley and Bossière, 2000 and references 828 therein) mention a possible link between the $\mathrm{OMZ}$ and even the southern part of SPZ and 829 the GTMZ zones through the Porto-Tomar-Ferreira do Alentejo fault (PTFA). The attempt to 830 justify the Monchique-Sta Clara de Sabóia alignment with a southward prolongation of the 831 PTFA shear zone has been also recently suggested by other authors (Arenas et al., 2016a; 832 Fernández et al., 2017, 2016; Fernández and Arenas, 2015); however, neither the proposed 833 location, which diverge to the west, nor its signature is evident in our tomograms. In our 834 view, the possible extension GTMZ-OMZ in the form suggested by these authors is not 835 supported by our model.

837 The low Vp anomaly in western SPZ is limited N-NW by the OA fault, to the south by the 838 strong signal associated with the Monchique Massif and its eastward limit eventually being 839 marked by the MST lineament. This area corresponds essentially to the Brejeira formation 840 ("Grupo de Flysch do Baixo Alentejo", in Oliveira et al., 1979) which is essentially composed 841 by greywacke lithologies and black mud shales, defining a characteristic basin in the 842 southwest SPZ border.

844 The Monchique Massif $(\mathrm{M})$ is characterized by a still active pneumatolytical hydrothermal 845 intrusion, with water with anomalous mineralization and some low temperature (bellow $8466^{\circ} \mathrm{C}$ ) geothermal springs (Bastos, 2011; Lourenço and Cruz, 2006; Lourenço, 1998), the 
847 mineralization indicating very deep circulation - with deep crustal values (González Clavijo 848 and Valadares, 2003; Miranda et al., 2009; Rock, 1978; Valadares, 2004). At the surface the 849 observed seismic cluster is not evidently associated with any kind of alignments or long fault 850 systems. Geomorphological criteria clearly displays some uplift of $300-350 m$ from the 851 Pliocene to the present day, including 100m uplift in the current Quaternary, paleoseismites 852 justifying intense seismic vibration and sedimentary liquefaction and fluidized material in the 853 Quaternary (Dias and Cabral 2002).

\section{Conclusions}

In this work, we present the first Local Earthquake Tomography study covering mainland Portugal and part of southern Galicia in Spain. This is one of the studies contributing to the knowledge of the seismic structure of the lithosphere, following the massive deployments of broadband seismic stations by projects WILAS in Portugal (2010-2012) and TOPOIBERIA in Spain (2007-2013).

Due to the irregular seismic activity rate in Portugal, especially in the north, the observation period of the WILAS project was expanded to include additional data. Thus, the analyzed period spans a period of 15 years, from 2000 to 2014, allowing a good and dense ray coverage of the study area. The data selection criteria were set to increase the maximum confidence in the results as possible: each selected event had to be registered by a minimum of 6-8 stations, depending if it was located in the north or the south, and a minimum of 8-10 $\mathrm{P}$ or $\mathrm{S}$ readings. Also, since for certain epicentral distances several incongruences were detected in the picking, additional criteria was applied to clean the dataset and reduce has

871 much as possible the uncertainty regarding the seismic phases arrival times. The main price paid for such cautious approach was the lack of very long seismic travel-paths, in effect not

873 allowing the imaging of the lower crust.

875 The remaining selected dataset, comprising 2640 events recorded over a variable seismic 876 network of over 100 stations both in Portugal and Spain, allowed the calculation of a 3D 877 model with the distribution of $V p$ and $V p / V s$ on a grid with an irregular design. With 
878 exception of the mid-lower crustal levels, the model presents a good resolution although with some N-S stretching of the anomalies in the center part of the country.

881 The complex history of the assemblage of the crust beneath Western Iberia is well-marked in 882 the final models. The arcuate shape of the Ibero-Armorican Arc can be perceived over the 883 general pattern of the $\mathrm{Vp}$ and $\mathrm{Vp} / \mathrm{Vs}$ anomalies, albeit local perturbations some of which 884 induced by the inversion grid setup. The $V p$ values are on average higher in the north, decreasing southward and westward into the Iberian margin.

887 As should be expected and according to several previous studies, the heterogeneity observed on the surface geology of the Galicia-Tras-os-Montes Zone is well marked in the tomograms, 889 a relatively thin layer over the smoother structure of the Centro Iberia Zone $\mathrm{ClZ}$. The $\mathrm{ClZ}$ 890 block confined between the Porto-Tomar-Ferreira do Alentejo shear zone and the Manteigas891 Bragança fault have generally higher $\mathrm{Vp}$ values to the rest of the $\mathrm{Cl}$, enhancing the contrast 892 with the Lusitanian Basin to the west.

894 The Ossa Morena Zone is the more complex area of our model, its heterogeneity signature 895 increasing to the SW, with a relatively smooth CIZ-OMZ transition as compared with the 896 highly complex SPZ-OMZ transition. Within the OMZ the increase in complexity is marked by 897 the alignment composed by the Ciborro and Serra de Ossa faults, marked by the observed 898 seismic alignment. The South Portuguese Zone presents bigger heterogeneity than the surface geology suggested, in particular, a W-E segmentation of its upper crust with a corresponding increase in the Vp values. The SW tip of the model presents significant heterogeneity, besides high seismicity rate around the Monchique Massif, whereas to the SE a diffuse observed

904 seismicity is hardly correlatable with any known surface structure.

906 Other significant features are the low Vp values associated with the Mesocenozoic rocks 907 outcropping in the Lusitanian and Algarve basins, and the low Vp and high Vp/Vs values of the sedimentary cover of the Lower-Tagus and Sado Basin. 
The seismicity distribution also displays a complex pattern, mainly reflecting the interaction

911 between inherited Variscan or tardi-Variscan structures, that were reactivated, with more

912 recent fault systems created during the rifting stages of the Atlantic and diapir magmatic

913 intrusions.

\section{Acknowledgments}

The authors are grateful to the Instituto Português do Mar e da Atmosfera (IPMA) for the providing of the catalogue data used in this study. The seismic stations used in the catalogue are owned and/or operated by IPMA (PM), by the IGN-Instituto Geográfico Nacional, Spain (ES), by the GEOFON program of the German Deutsches GeoForschungsZentrum GFZ (GE), by IST - Instituto Superior Técnico (IP), IDL-Instituto Dom Luiz (LX), CITEUC-Centro de de Investigação da Terra e do Espaço da Universidade de Coimbra (SS) and ICT-Instituto de Ciências da Terra, Universidade de Évora (WM). Theinstruments for the WILAS temporary deployment were providedby the Geophysical Instrument Pool of the GFZ Potsdam (GIPP), Germany.The temporary WILAS and IberArray deployment were registeredunder FDSN network codes 8A and IB. The GMT-Generic MappingTools (Wessel and Smith, 1998)were used for figure plotting.

928 The authors wish to acknowledge projects WILAS-Westlberia Lithosphere and Astenosphere Structure (PTDC/CTEGIX/097946/2008) and QuakeLoc-PT-Precise earthquake locations in mainlandPortugal and adjacent offshore (PTDC/GEO-FIQ/3522/2012), both funded by Fundação para a Ciência e Tecnologia, for theirmajor contributions to this work. This is a contribution for project SPIDER-Seismogenic Processes In slowly DEforming Regions (PTDC/GEO-FIQ/2590/2014). This publication was supported by project FCT

\section{References}

Afilhado, A., Matias, L., Shiobara, H., Hirn, A., Mendesvictor, L., Shimamura, H., 2008. From unthinned continent to ocean: the deep structure of the west iberia passive continental margin at $38^{\circ} \mathrm{n}$. Tectonophysics $458,9-50$.

Almeida, E., Monteiro Santos, F., Mateus, A., Heise, W., Pous, J., 2005. Magnetotelluric measurements in SW Iberia: New data for the Variscan crustal structures. Geophys. Res. Lett. 32, 1-4. doi:10.1029/2005GL022596

Almeida, E., Pous, J., Santos, F.M., Fonseca, P., Marcuello, A., Queralt, P., Nolasco, R., Mendes-Victor, L.L., 2001. Electromagnetic imaging of a transpressional tectonics in SW Iberia. Geophys. Res. Lett. 28, 439-442. doi:10.1029/2000GL012037

Arenas, R., Díez Fernández, R., Rubio Pascual, F.J., Sánchez Martínez, S., Martín Parra, L.M., Matas, J., González del Tánago, J., Jiménez-Díaz, A., Fuenlabrada, J.M., Andonaegui, P., Garcia-Casco, A., 2016a. The Galicia-Ossa-Morena Zone: Proposal for a new zone of the Iberian Massif. Variscan implications. Tectonophysics 681, 135-143. doi:10.1016/j.tecto.2016.02.030 
Arenas, R., Sánchez Martínez, S., Díez Fernández, R., Gerdes, A., Abati, J., Fernández-Suárez, J., Andonaegui, P., González Cuadra, P., López Carmona, A., Albert, R., Fuenlabrada, J.M., Rubio Pascual, F.J., 2016b. Allochthonous terranes involved in the Variscan suture of NW Iberia: A review of their origin and tectonothermal evolution. Earth-Science Rev. 161, 140-178. doi:10.1016/j.earscirev.2016.08.010

Ayarza, P., Palomeras, I., Carbonell, R., Afonso, J.C., Simancas, F., 2010. A wide-angle upper mantle reflector in SW Iberia: Some constraints on its nature. Phys. Earth Planet. Inter. 181, 88-102. doi:10.1016/j.pepi.2010.05.004

Banda, E., 1988. Crustal parameters in the Iberian Peninsula. Phys. Earth Planet. Inter. 51, 222-225. doi:10.1016/0031-9201(88)90048-9

Bastos, C., 2011. From sulphur to perfume: spa and SPA at Monchique, Algarve. Anthropol. Med. 18, 37-53. doi:10.1080/13648470.2010.525872

Boillot, G., Grimaud, S., Mauffret, A., Mougenot, D., Kornprobst, J., Mergoil-Daniel, J., Torrent, G., 1980. Ocean-continent boundary off the Iberian margin: A serpentinite diapir west of the Galicia Bank. Earth Planet. Sci. Lett. 48, 23-34. doi:10.1016/0012$821 \times(80) 90166-1$

Borges, J.F., Silva, H.G., Torres, R.J.G., Caldeira, B., Bezzeghoud, M., Furtado, J.A., Carvalho, J., 2016. Inversion of ambient seismic noise HVSR to evaluate velocity and structural models of the Lower Tagus Basin, Portugal. J. Seismol. doi:10.1007/s10950-016-9564-X

Braeuer, B., Asch, G., Hofstetter, R., Haberland, C., Jaser, D., El-Kelani, R., Weber, M., 2012. High-resolution local earthquake tomography of the southern Dead Sea area. Geophys. J. Int. 191, 881-897. doi:10.1111/j.1365-246X.2012.05668.x

Cabral, J., 1995. Neotectónica em Portugal Continental, Mem. Inst. Geol. E Min. Lisbon.

Cabral, J., 1989. An example of intraplate neotectonic activity, Vilariça Basin, northeast Portugal. Tectonics 8, 285-303. doi:10.1029/TC008i002p00285

Cabral, J., Moniz, C., Batlló, J., Figueiredo, P., Carvalho, J., Matias, L., Teves-Costa, P., Dias, R., Simão, N., 2013. The 1909 Benavente (Portugal) earthquake: Search for the source. Nat. Hazards 69, 1211-1227. doi:10.1007/s11069-011-0062-8

Cabral, J., Ribeiro, P., Figueiredo, P., Pimentel, N., Martins, a., 2004. The Azambuja fault: An active structure located in an intraplate basin with significant seismicity (Lower Tagus Valley, Portugal). J. Seismol. 8, 347-362. doi:10.1023/B:JOSE.0000038450.23032.68

Carbonell, R., Simancas, F., Juhlin, C., Pous, J., Pérez-Estaún, A., Gonzalez-Lodeiro, F., Muñoz, G., Heise, W., Ayarza, P., 2004. Geophysical evidence of a mantle derived intrusion in SW Iberia. Geophys. Res. Lett. 31, L11601. doi:10.1029/2004GL019684

Carrilho, F., Teves-Costa, P., Morais, I., Pagarete, J., Dias, R., 2004. GEOALGAR Project: First Results on Seismicity and Fault-plane Solutions. Pure Appl. Geophys. 161, 589-606. doi:10.1007/s00024-003-02464-3

Carvalho, J., Pinto, C., Dias, R., Rabeh, T., Torres, L., Borges, J., Torres, R., Duarte, H., 2016. Tectonic evolution of an intraplate basin: The Lower Tagus Cenozoic Basin, Portugal. Basin Res. 1-22. doi:10.1111/bre.12193

Carvalho, J., Rabeh, T., Cabral, J., Carrilho, F., Miranda, J.M., 2008. Geophysical characterization of the Ota-Vila Franca de Xira-Lisbon-Sesimbra fault zone, Portugal. Geophys. J. Int. 174, 567-584. doi:10.1111/j.1365-246X.2008.03791.x

Carvalho, J., Rabeh, T., Dias, R., Dias, R., Pinto, C., Oliveira, T., Cunha, T., Borges, J., 2014. Tectonic and neotectonic implications of a new basement map of the Lower Tagus Valley, Portugal. Tectonophysics 617, 88-100. doi:10.1016/j.tecto.2014.01.017

Chaminé, H.I., Gama Pereira, L.C., Fonseca, P.E., Moço, L.P., Fernandes, J.P., Rocha, F.T., Flores, 

Tectonostratigraphy of Middle and Upper Palaeozoic black shales from the Porto-TomarFerreira do Alentejo shear zone (W Portugal): New perspectives on the Iberian Massif. Geobios 36, 649-663. doi:10.1016/j.geobios.2003.03.002

Chiarabba, C., Piccinini, D., De Gori, P., 2009. Velocity and attenuation tomography of the Umbria Marche 1997 fault system: Evidence of a fluid-governed seismic sequence. Tectonophysics 476, 73-84. doi:10.1016/j.tecto.2009.04.004

Crispim, J.A., 1986. Dinâmica Cársica da região de Ansião.

Crispim, J.A., Ribeiro, A., 1986. Tectónica extensional no bordo leste do Fosso Lusitaniano (área de Ancião). Maleo 2, 17.

Custodio, S., Dias, N. a., Caldeira, B., Carrilho, F., Carvalho, S., Corela, C., Diaz, J., Narciso, J., Madureira, G., Matias, L., Haberland, C., 2014. Ambient Noise Recorded by a Dense Broadband Seismic Deployment in Western Iberia. Bull. Seismol. Soc. Am. 104, 29853007. doi:10.1785/0120140079

Custódio, S., Dias, N. a., Carrilho, F., Góngora, E., Rio, I., Marreiros, C., Morais, I., Alves, P., Matias, L., 2015. Earthquakes in western Iberia: improving the understanding of lithospheric deformation in a slowly deforming region. Geophys. J. Int. 203, 127-145. doi:10.1093/gji/ggv285

Custódio, S., Lima, V., Vales, D., Cesca, S., Carrilho, F., 2016. Imaging active faulting in a region of distributed deformation from the joint clustering of focal mechanisms and hypocentres: Application to the Azores-western Mediterranean region. Tectonophysics 676, 70-89. doi:10.1016/j.tecto.2016.03.013

De Vicente, G., Cloetingh, S., Van Wees, J.D., Cunha, P.P., 2011. Tectonic classification of Cenozoic Iberian foreland basins. Tectonophysics 502, 38-61. doi:10.1016/j.tecto.2011.02.007

Dias, N.A., Matias, L., Lourenco, N., Madeira, J., Carrilho, F., Gaspar, J., 2007. Crustal seismic velocity structure near faial and pico islands (azores), from local earthquake tomography. Tectonophysics 445, 301-317. doi:10.1016/j.tecto.2007.09.001

Dias, R., Ribeiro, A., 1995. The Ibero-Armorican Arc: A collision effect against an irregular continent? Tectonophysics 246, 113-128. doi:10.1016/0040-1951(94)00253-6

Díaz, J., Gallart, J., 2009. Crustal structure beneath the Iberian Peninsula and surrounding waters: A new compilation of deep seismic sounding results. Phys. Earth Planet. Inter. 173, 181-190. doi:10.1016/j.pepi.2008.11.008

Díaz, J., Gallart, J., Córdoba, D., Senos, L., Matias, L., SuriÑach, E., Hirn, A., Maguire, P., $1993 a$. A deep seismic sounding investigation of lithospheric heterogeneity and anisotropy beneath the Iberian Peninsula. Tectonophysics 221, 35-51. doi:10.1016/00401951(93)90026-G

Díaz, J., Gallart, J., Córdoba, D., Senos, L., Matias, L., SuriÑach, E., Hirn, A., Maguire, P., 1993b. A deep seismic sounding investigation of lithospheric heterogeneity and anisotropy beneath the Iberian Peninsula. Tectonophysics 221, 35-51. doi:10.1016/00401951(93)90026-G

Díaz, J., Gallart, J., Pulgar, J. a., Ruiz, M., Pedreira, D., 2009. Crustal structure beneath NorthWest Iberia imaged using receiver functions. Tectonophysics 478, 175-183. doi:10.1016/j.tecto.2009.08.003

Diaz, J., Villasenor, a., Morales, J., Pazos, a., Cordoba, D., Pulgar, J., Garcia-Lobon, J.L., Harnafi, M., Carbonell, R., Gallart, J., 2010. Background Noise Characteristics at the IberArray Broadband Seismic Network. Bull. Seismol. Soc. Am. 100, 618-628. 
Dündar, S., Dias, N.A., Silveira, G., Kind, R., Vinnik, L., Matias, L., Bianchi, M., 2016. Estimation of the Crustal Bulk Properties Beneath Mainland Portugal from P-Wave Teleseismic Receiver Functions. Pure Appl. Geophys. 173, 1949-1970. doi:10.1007/s00024-0161257-4

Eberhart-Phillips, D., 1986. Three-Dimensional Velocity Structure in Northern California Coast Ranges From Inversion of Local Earthquake Arrival Times. Bull. Seismol. Soc. Am. 76, 1025-1052.

Eberhart-Phillips, D., Michael, A.J., 1998. Seismotectonics of the Loma Prieta, California, region determined from three-dimensional V p , V p / V s, and seismicity. J. Geophys. Res. Solid Earth 103, 21099-21120. doi:10.1029/98JB01984

Ehsan, S.A., Carbonell, R., Ayarza, P., Martí, D., Poyatos, D.M., Pérez-Estaún, A., 2015. The structure and nature of the Moho beneath Central Iberia. Tectonophysics 663, 275-289. doi:10.1016/j.tecto.2015.08.011

El Moudnib, L., Villaseñor, A., Harnafi, M., Gallart, J., Pazos, A., Serrano, I., Córdoba, D., Pulgar, J. a., Ibarra, P., Himmi, M.M., Chourak, M., 2015. Crustal structure of the BeticRif system, western Mediterranean, from local earthquake tomography. Tectonophysics 643, 94-105. doi:10.1016/j.tecto.2014.12.015

Fernandes, R.M.S., 2003. The relative motion between Africa and Eurasia as derived from ITRF2000 and GPS data. Geophys. Res. Lett. 30, 1828. doi:10.1029/2003GL017089

Fernández, R.D., Arenas, R., 2015. The Late Devonian Variscan suture of the Iberian Massif: A correlation of high-pressure belts in NW and SW Iberia. Tectonophysics 654, 96-100. doi:10.1016/j.tecto.2015.05.001

Fernández, R.D., Arenas, R., Pereira, M.F., Sánchez-Martínez, S., Albert, R., Mart??n Parra, L.M., Rubio Pascual, F.J., Matas, J., 2016. Tectonic evolution of Variscan Iberia: Gondwana-Laurussia collision revisited. Earth-Science Rev. 162, 269-292. doi:10.1016/j.earscirev.2016.08.002

Fernández, R.D., Fuenlabrada, J.M., Chichorro, M., Pereira, M.F., Sánchez-Martínez, S., Silva, J.B., Arenas, R., 2017. Geochemistry and tectonostratigraphy of the basal allochthonous units of SW Iberia (Évora Massif, Portugal): Keys to the reconstruction of pre-Pangean paleogeography in southern Europe. Lithos 268-271, 285-301. doi:10.1016/j.lithos.2016.10.031

Ferrão, C., Bezzeghoud, M., Caldeira, B., Borges, J.F., 2016. The Seismicity of Portugal and Its Adjacent Atlantic Region from 1300 to 2014: Maximum Observed Intensity (MOI) Map. Seismol. Res. Lett. 87, 743-750. doi:10.1785/0220150217

Flecha, I., Palomeras, I., Carbonell, R., Simancas, F., Ayarza, P., Matas, J., González-Lodeiro, F., Pérez-Estaún, a., 2009. Seismic imaging and modelling of the lithosphere of SW-Iberia. Tectonophysics 472, 148-157. doi:10.1016/j.tecto.2008.05.033

Fonseca, P., Munhá, J., Pedro, J., Rosas, F., Moita, P., Araújo, A., Leal, N., 1999. Variscan Ophiolites and high-pressure metamorfism in Southern Iberia. Ofioliti 24, 259-268. doi:10.4454/ofioliti.v24i2.106

Fonseca, P., Ribeiro, A., 1993. Tectonics of the Beja-Acebuches Ophiolite: a major suture in the Iberian Variscan Foldbelt. Geol. Rundschau 82, 440-447. doi:10.1007/BF00212408

Foulger, G.R., Miller, A.D., Julian, B.R., Evans, J.R., 1995. Three-dimensional vp and vp/vs structure of the Hengill Triple Junction and geothermal area, Iceland, and the repeatability of tomographic inversion. Geophys. Res. Lett. 22, 1309-1312.

Ghose, R., Carvalho, J., Loureiro, A., 2013. Signature of fault zone deformation in near-surface 
soil visible in shear wave seismic reflections. Geophys. Res. Lett. 40, n/a-n/a. doi:10.1002/grl.50241

Gonzalez-Fernandez, A., Cordoba, D., Matias, L.M., Torne, M., 2001. Seismic crustal structure in the Gulf of Cadiz (SW Iberian Peninsula). Mar. Geophys. Res. 22, 207-223.

Gonzalez, A., Torne, M., Cordoba, D., Vidal, N., Matias, L.M., Diaz, J., 1996. Crustal thinning in the Southwestern Iberia Margin. Geophys. Res. Lett. 23, 2477-2480.

González, A., Torné, M., Córdoba, D., Vidal, N., Matias, L.M., Díaz, J., 1996. Crustal thinning in the Southwestern Iberia Margin. Geophys. Res. Lett. 23, 2477. doi:10.1029/96GL02299

González Clavijo, E.J., Valadares, V., 2003. O maciço alcalino de Monchique, SW português : estrutura e modelo de instalação na crosta superior. Comun. do Inst. Geológico e Min. 90, 43-64.

Gutiérrez-Alonso, G., Collins, A.S., Fernández-Suárez, J., Pastor-Galán, D., González-Clavijo, E., Jourdan, F., Weil, A.B., Johnston, S.T., 2015. Dating of lithospheric buckling: 40Ar/39Ar ages of syn-orocline strike-slip shear zones in northwestern Iberia. Tectonophysics 643, 44-54. doi:10.1016/j.tecto.2014.12.009

Haslinger, F., Kissling, E., Ansorge, J., Hatzfeld, D., Papadimitriou, E., Karakostas, V., Makropoulos, K., Kahle, H.-G., Peter, Y., 1999. 3D crustal structure from local earthquake tomography around the Gulf of Arta (Ionian region, NW Greece). Tectonophysics 304, 201-218. doi:10.1016/S0040-1951(98)00298-4

Hunsen, S., 1999. Local Earthquake Tomography of a Convergent Margin, North Chile: A Combined On- and Offshore Study, PhD Thesis. ed, Rays. Christian-Albrechts-Universität, Kiel.

Husen, S., Kissling, E., Quintero, R., 2002. Tomographic evidence for a subducted seamount beneath the Gulf of Nicoya, Costa Rica: The cause of the $1990 \mathrm{Mw}=7.0$ Gulf of Nicoya earthquake. Geophys. Res. Lett. 29, 1238. doi:10.1029/2001GL014045

Husen, S., Quintero, R., Kissling, E., Hacker, B., 2003. Subduction-zone structure and magmatic processes beneath Costa Rica constrained by local earthquake tomography and petrological modelling. Geophys. J. Int. 155, 11-32. doi:10.1046/j.1365246X.2003.01984.x

Jeanniot, L., Kusznir, N., Mohn, G., Manatschal, G., Cowie, L., 2016. Constraining lithosphere deformation modes during continental breakup for the Iberia-Newfoundland conjugate rifted margins. Tectonophysics 680, 28-49. doi:10.1016/j.tecto.2016.05.006

Julia, J., Mejia, J., 2004. Thickness and vp/vs ratio variation in the iberian crust. Geophys. J. Int. 156, 59-72. doi:10.1111/j.1365-246X.2004.02127.x

Kissling, E., Ellsworth, W.L., Eberhart-Phillips, D., Kradolfer, U., 1994. Initial reference models in local earthquake tomography. J. Geophys. Res. 99, 19635-19646. doi:10.1029/93JB03138

Kissling, E., Husen, S., Haslinger, F., 2001. Model parametrization in seismic tomography: a choice of consequence for the solution quality. Phys. Earth Planet. Inter. 123, 89-101. doi:10.1016/S0031-9201(00)00203-X

Kohler, M.D., Eberhart-Phillips, D., 2002. Three-dimensional lithospheric structure below the New Zealand Southern Alps. J. Geophys. Res. 107, 2225. doi:10.1029/2001JB000182

Koulakov, I., 2009. Out-of-Network Events Can Be of Great Importance for Improving Results of Local Earthquake Tomography. Bull. Seismol. Soc. Am. 99, 2556-2563. doi:10.1785/0120080365

Linnemann, U., Pereira, M.F., Jeffries, T.E., Drost, K., Gerdes, A., 2008. The Cadomian Orogeny and the opening of the Rheic Ocean: The diacrony of geotectonic processes constrained 
by LA-ICP-MS U-Pb zircon dating (Ossa-Morena and Saxo-Thuringian Zones, Iberian and Bohemian Massifs). Tectonophysics 461, 21-43. doi:10.1016/j.tecto.2008.05.002

Lourenço, C., Cruz, J., 2006. Aproveitamentos geotérmicos em Portugal Continental, in: XV Encontro Nacional Do Colégio de Engenharia Geológica E de Minas Da Ordem Dos Engenheiros. pp. 1-9.

Lourenço, M.C., 1998. Recursos Geotermicos de Baixa Entalpia em Portugal, in: $4^{\circ}$ Congresso Da Água. pp. 1-11.

Mancilla, F., Diaz, J., 2015. High resolution Moho topography map beneath Iberia and Northern Morocco from receiver function analysis. Tectonophysics 663, 203-211. doi:10.1016/j.tecto.2015.06.017

Martín-González, F., 2009. Cenozoic tectonic activity in a Variscan basement: Evidence from geomorphological markers and structural mapping (NW Iberian Massif). Geomorphology 107, 210-225. doi:10.1016/j.geomorph.2008.12.008

Martínez-Díaz, J.J., Capote, R., Tsige, M., Villamor, P., Martín-González, F., Insua-Arévalo, J.M., 2006. Seismic triggering in a stable continental area: The Lugo 1995-1997 seismic sequences (NW Spain). J. Geodyn. 41, 440-449. doi:10.1016/j.jog.2006.01.001

Matias, L., 1996. A sismologia experimental na modelação da crusta em Portugal Continental. Lisbon.

Matte, P., 2001. The Variscan collage and orogeny (480-290 Ma) and the tectonic definition of the Armorica microplate: a review. Terra Nov. 13, 122-128. doi:10.1046/j.13653121.2001.00327.x

Matte, P., 1986. Tectonics and plate tectonics model for the Variscan belt of Europe. Tectonophysics 126, 329-374. doi:10.1016/0040-1951(86)90237-4

Miranda, R., Valadares, V., Terrinha, P., Mata, J., Azevedo, M.D.R., Gaspar, M., Kullberg, J.C., Ribeiro, C., 2009. Age constraints on the Late Cretaceous alkaline magmatism on the West Iberian Margin. Cretac. Res. 30, 575-586. doi:10.1016/j.cretres.2008.11.002

Mueller, S., Prodehl, C., Mendes, A.S., Sousa Moreira, V., 1973. Crustal structure in the southwestern part of the Iberian Peninsula. Tectonophysics 20, 307-318. doi:10.1016/0040-1951(73)90120-0

Nance, R.D., Guti??rrez-Alonso, G., Keppie, J.D., Linnemann, U., Murphy, J.B., Quesada, C., Strachan, R.A., Woodcock, N.H., 2010. Evolution of the Rheic Ocean. Gondwana Res. 17, 194-222. doi:10.1016/j.gr.2009.08.001

Neves, M.C., Cabral, J., Luttrell, K., Figueiredo, P., Rockwell, T., Sandwell, D., 2015. The effect of sea level changes on fault reactivation potential in Portugal. Tectonophysics 658, 206-220. doi:10.1016/j.tecto.2015.07.023

Nocquet, J.-M., 2012. Present-day kinematics of the Mediterranean: A comprehensive overview of GPS results. Tectonophysics 579, 220-242. doi:10.1016/j.tecto.2012.03.037

Oliveira, J.T., Horn, M., Paproth, E., 1979. Preliminary note on the stratigraphy of the Baixo Alentejo Flysch Group, Carboniferous of Southern Portugal and on the palaeogeographic development, compared to corresponding units in Northwest Germany. Comun. dos Serviços Geológicos Port. 65, 151-168.

Pais, J., Cunha, P.P., Pereira, D.I., Legoinha, P., Dias, R., Moura, D., Silveira, A., Kullberg, J.C., Delgado, J.A., 2012. The Paleogene and Neogene of Western Iberia (Portugal): A Cenozoic Record in the European Atlantic Domain. Springer-Verlag, Berlin Heidelberg. doi:10.1007/978-3-642-22401-0

Palomeras, I., Carbonell, R., Ayarza, P., Fernàndez, M., Simancas, J.F., Poyatos, D.M., González Lodeiro, F., Pérez-Estaún, A., 2011. Geophysical model of the lithosphere across the 
Variscan Belt of SW-Iberia: Multidisciplinary assessment. Tectonophysics 508, 42-51. doi:10.1016/j.tecto.2010.07.010

Pereira, R., Alves, T.M., 2013. Crustal deformation and submarine canyon incision in a MesoCenozoic first-order transfer zone (SW Iberia, North Atlantic Ocean). Tectonophysics 601, 148-162. doi:10.1016/j.tecto.2013.05.007

Pereira, R., Alves, T.M., Mata, J., 2016. Alternating crustal architecture in West Iberia: a review of its significance in the context of NE Atlantic rifting. J. Geol. Soc. London. jgs2016-050. doi:10.1144/jgs2016-050

Poyatos, D.M., Carbonell, R., Palomeras, I., Simancas, J.F., Ayarza, P., Martí, D., Azor, A., Jabaloy, A., González Cuadra, P., Tejero, R., Martín Parra, L.M., Matas, J., González Lodeiro, F., Pérez-Estaún, A., García Lobón, J.L., Mansilla, L., 2012. Imaging the crustal structure of the Central Iberian Zone (Variscan Belt): The ALCUDIA deep seismic reflection transect. Tectonics 31, n/a-n/a. doi:10.1029/2011TC002995

Prodehl, C., Moreira, V.S., Mueller, S., Mendes, A.S., 1975. Deep seismic sounding experiments in central and southern Portugal, in: General Assembly of the European Seimological Commission 14th-Berlin. DDR National-Komitee für Geodäsie und Geophysik, Berlin, pp. 261-266.

Rawlinson, N., Spakman, W., 2016. On the use of sensitivity tests in seismic tomography. Geophys. J. Int. 205, 1221-1243. doi:10.1093/gji/ggw084

Ribeiro, A., Cabral, J., Baptista, R., Matias, L., 1996. Stress pattern in Portugal mainland and the adjacent Atlantic region, West Iberia. Tectonics 15, 641-659. doi:10.1029/95TC03683

Ribeiro, A., Kullberg, M.., Kullberg, J.., Manuppella, G., Phipps, S., 1990. A review of Alpine tectonics in Portugal: Foreland detachment in basement and cover rocks. Tectonophysics 184, 357-366. doi:10.1016/0040-1951(90)90448-H

Ribeiro, A., Munhá, J., Dias, R., Mateus, A., Pereira, E., Ribeiro, L., Fonseca, P., Araújo, A., Oliveira, T., Romão, J., Chaminé, H., Coke, C., Pedro, J., 2007. Geodynamic evolution of the SW Europe Variscides. Tectonics 26, n/a-n/a. doi:10.1029/2006TC002058

Ribeiro, A., Munhá, J., Mateus, A., Fonseca, P., Pereira, E., Noronha, F., Romão, J., Rodrigues, J., Castro, P., Meireles, C., Ferreira, N., 2009. Mechanics of thick-skinned Variscan overprinting of Cadomian basement (Iberian Variscides). Comptes Rendus - Geosci. 341, 127-139. doi:10.1016/j.crte.2008.12.003

Ribeiro, L.M.J., Gonçalves, A.C.R., 2013. Contributo Para o Conhecimento Geomorfológico e Geológico da Área Envolvente do Couto Mineiro da Panasqueira. GOT - Geogr. Spat. Plan. J. 3, 93-116. doi:10.17127/got/2013.3.005

Rocha, J.P., Bezzeghoud, M., Caldeira, B., Borges, J.F., Dias, N., Matias, L., Dorbath, C., 2010. Tomografia sísmica da litosfera continental algarvia. e-Terra 10, 10-12.

Rock, N.M.S., 1978. Petrology and petrogenesis of the monchique alkaline complex, southern portugal. J. Petrol. 19, 171-214. doi:10.1093/petrology/19.2.171

Rockwell, T., Fonseca, J., Madden, C., Dawson, T., Owen, L.A., Vilanova, S., Figueiredo, P., 2009. Palaeoseismology of the Vilarica Segment of the Manteigas-Braganca Fault in northeastern Portugal, in: Reicherter, K., Michetti, A.M., Silva, P.G. (Eds.), Palaeoseismology: Historical and Prehistorical Records of Earthquake Ground Effects for Seismic Hazard Assessment. The Geological Society, London, Special Publications, London, pp. 237-258. doi:10.1144/SP316.15

Salah, M.K., 2013. Upper crustal structure beneath Southwest Iberia north of the convergent boundary between the Eurasian and African plates. Geosci. Front. 5, 845-854. 
doi:10.1016/j.gsf.2013.10.002

Salah, M.K., Chang, S.-J., Fonseca, J.F.B.D., 2011. Crustal structure beneath the Lower Tagus Valley, southwestern Iberia using joint analysis of teleseismic receiver functions and surface-wave dispersion. Geophys. J. Int. 184, 919-933. doi:10.1111/j.1365246X.2010.04891.x

Serpelloni, E., Vannucci, G., Pondrelli, S., Argnani, A., Casula, G., Anzidei, M., Baldi, P., Gasperini, P., 2007. Kinematics of the Western Africa-Eurasia plate boundary from focal mechanisms and GPS data. Geophys. J. Int. 169, 1180-1200. doi:10.1111/j.1365246X.2007.03367.x

Shelley, D., Bossière, G., 2000. A new model for the Hercynian Orogen of Gondwanan France and Iberia. J. Struct. Geol. 22, 757-776. doi:10.1016/S0191-8141(00)00007-9

Silveira, G., Afonso Dias, N., Villaseñor, A., 2013. Seismic imaging of the western Iberian crust using ambient noise: Boundaries and internal structure of the Iberian Massif. Tectonophysics 589, 186-194. doi:10.1016/j.tecto.2012.12.025

Simancas, J.F., 2003. Crustal structure of the transpressional Variscan orogen of SW Iberia: SW Iberia deep seismic reflection profile (IBERSEIS). Tectonics 22. doi:10.1029/2002TC001479

Simancas, J.F.., Carbonell, R., González Lodeiro, F., Pérez Estaún, A., Juhlin, C., Ayarza, P., Kashubin, A., Azor, A., Martínez Poyatos, D., Almodóvar, G.R., Pascual, E., Sáez, R., Expósito, I., 2003. Crustal structure of the transpressional Variscan orogen of SW Iberia: SW Iberia deep seismic reflection profile (IBERSEIS). Tectonics 22, n/a-n/a. doi:10.1029/2002TC001479

Simancas, J.F., Ayarza, P., Azor, A., Carbonell, R., Martínez Poyatos, D., Pérez-Estaún, A., González Lodeiro, F., 2013. A seismic geotraverse across the Iberian Variscides: Orogenic shortening, collisional magmatism, and orocline development. Tectonics 32, 1-16. doi:10.1002/tect.20035

Simancas, J.F., Carbonell, R., González Lodeiro, F., Pérez-Estaún, A., Juhlin, C., Ayarza, P., Azor, A., Martínez Poyatos, D., Almodóvar, G.R., Pascual, E., Sáez, R., Kashubin, A., Alonso, F., Alvares Marrón, J., Bohoyo, F., Castillo, S., Donaire, T., Expósito, I., Flecha, I., Galadi, E., Galindo Zaldívar, J., González, F., González Cuadra, P., Macías, I., Martí, D., Martin, A., Martín Parra, L.M., Nieto, J.M., Palm, H., Ruano, P., Ruiz, M., Toscano, M., 2004. The Seismic Crustal Structure of the Ossa-Morena Zone and its geological interpretation. J. Iber. Geol. 30, 133-142.

Simancas, J.F., Poyatos, D.M., Expósito, I., Azor, a., Lodeiro, F.G., 2001. The structure of a major suture zone in the SW Iberian Massif: the Ossa-Morena/Central Iberian contact. Tectonophysics 332, 295-308. doi:10.1016/S0040-1951(00)00262-6

Sousa Moreira, V., Mueller, S., Mendes, A.S., Prodehl, C., 1978. The deep structure of southern Portugal, in: Geodinámica de La Cordillera Bética Y Mar de Alborán. University of Granada, pp. 35-41.

Sousa Moreira, V., Prodehl, C., Mueller, S., Mendes, A.S., 1983. Crustal structure of western Portugal, in: Bisztricsàny, E., Szeidovitz, G.Y. (Eds.), 17th Gen. Assoc. Eur. Seismol. Comm. Elsevier B.V., Amsterdam, pp. 529-532.

Téllez, J., Córdoba, D., 1998. Crustal shear-wave velocity and Poisson's ratio distribution in northwest Spain. J. Geodyn. 25, 35-45. doi:10.1016/S0264-3707(97)00002-1

Téllez, J., Matias, L.M., Córdoba, D., Mendes-Victor, L.A., 1993. Structure of the crust in the schistose domain of Galicia-Tras-os-Montes (NW Iberian Peninsula). Tectonophysics 221, 81-93. doi:10.1016/0040-1951(93)90029-J 
Thurber, C., Eberhart-Phillips, D., 1999. Local earthquake tomography with flexible gridding. Comput. Geosci. 25, 809-818. doi:10.1016/S0098-3004(99)00007-2

Thurber, C.H., 1983. Earthquake locations and three-dimensional crustal structure in the Coyote Lake Area, central California. J. Geophys. Res. 88, 8226. doi:10.1029/JB088iB10p08226

Toomey, D.R., Foulger, G.R., 1989. Tomographic inversion of local earthquake data from the Hengill-Grensdalur Central Volcano Complex, Iceland. J. Geophys. Res. 94, 17497. doi:10.1029/JB094iB12p17497

Valadares, V., 2004. O Complexo Alcalino de Monchique: novos dados de cartografia, geoquímica e geocronologia. Fac. Ciências, Univ. Lisboa.

Vázquez, J.T., Medialdea, T., Ercilla, G., Somoza, L., Estrada, F., Fernández Puga, M.C., Gallart, J., Gràcia, E., Maestro, A., Sayago, M., 2008. Cenozoic deformational structures on the Galicia Bank Region (NW Iberian continental margin). Mar. Geol. 249, 128-149. doi:10.1016/j.margeo.2007.09.014

Victor, L.A.M., Hirn, A., VEINANTE, J., 1980. A Seismic Section Across The Tagus Valley, Portugal - Possible Evolution Of The Crust. Ann. Geophys. 36, 469-476.

Vieira Da Silva, N., Mateus, A., Monteiro Santos, F., Almeida, E., Pous, J., 2007. 3-D electromagnetic imaging of a palaeozoic plate-Tectonic boundary segment in SW Iberian variscides (S Alentejo, Portugal). Tectonophysics 445, 98-115. doi:10.1016/j.tecto.2007.06.006

Villamor, P., Capote, R., Stirling, M.W., Tsige, M., Berryman, K.R., Martínez-Díaz, J.J., MartínGonzález, F., 2012. Contribution of active faults in the intraplate area of Iberia to seismic hazard: The Alentejo-Plasencia Fault. J. Iber. Geol. 38, 85-111. doi:10.5209/rev_JIGE.2012.v38.n1.39207

Wachilala, P.E.M., 2015. Sismotectónica da região de Ciborro-Arraiolos e sua relação com a Geomorfologia local. Universidade de Évora.

Wessel, P., Smith, W.H.F., 1998. New, improved version of generic mapping tools released. Eos, Trans. Am. Geophys. Union 79, 579-579. doi:10.1029/98EO00426

Wilson, J.T., 1966. Did the Atlantic Close and then Re-Open? Nature 211, 676-681. doi:10.1038/211676a0

Zelt, C. a., Smith, R.B., 1992. Seismic traveltime inversion for 2-D crustal velocity structure. Geophys. J. Int. 108, 16-34. doi:10.1111/j.1365-246X.1992.tb00836.x

Zelt, C. a, Ellis, R.M., 1988. Practical and efficient ray tracing in two-dimensional media for rapid traveltime and amplitude forward modeling. Can. J. Explor. Geophys. 24, 16-31. 


\section{FIGURES}

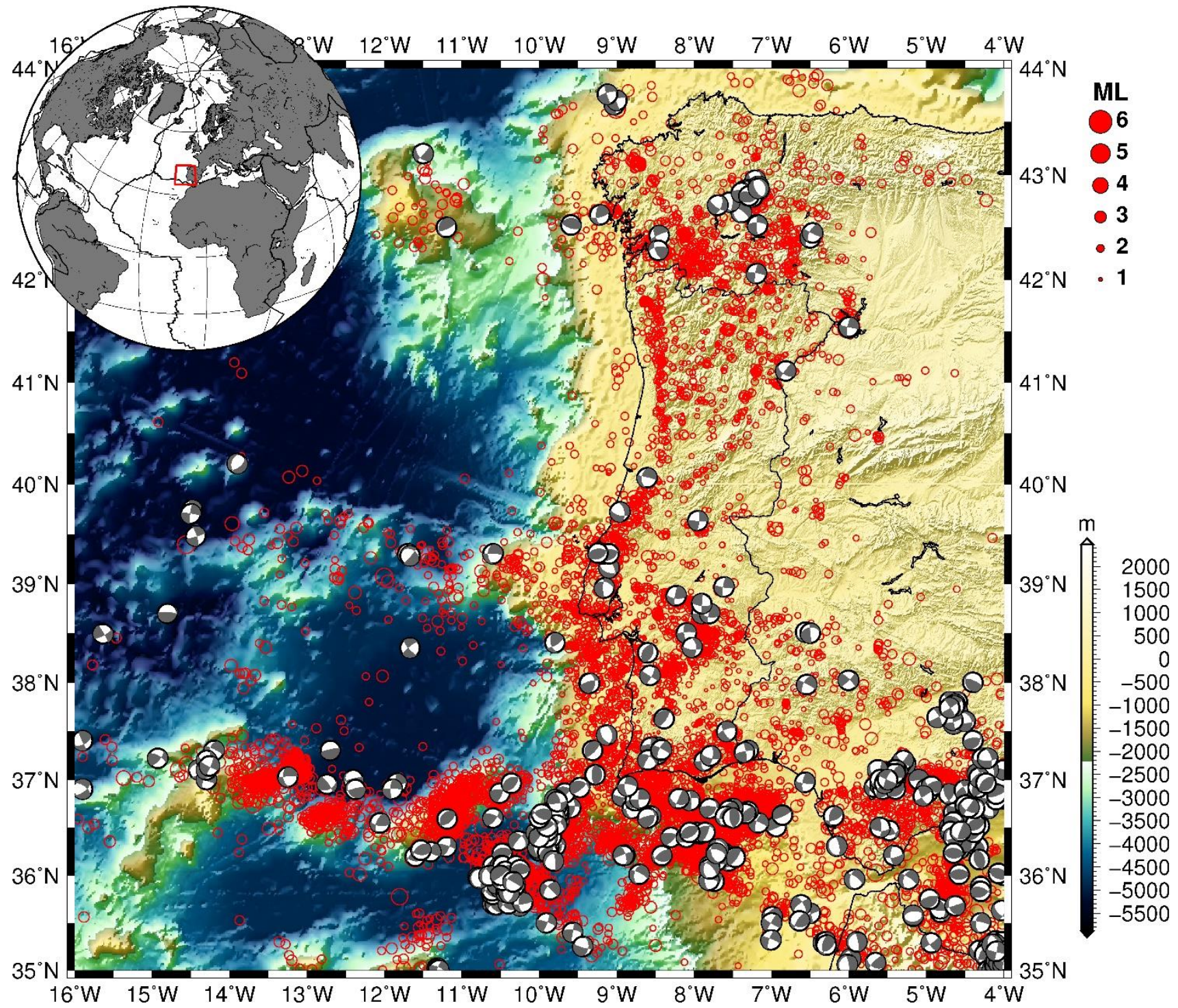

Figure 1 - Recorded seismicity for the period 2000-2014 in the area of Western Iberia, including mainland Portugal, from IPMA's catalogue and focal mechanisms from Custódio et al. (2016). Inset: location of the study area and the relation with the main plate limits. 


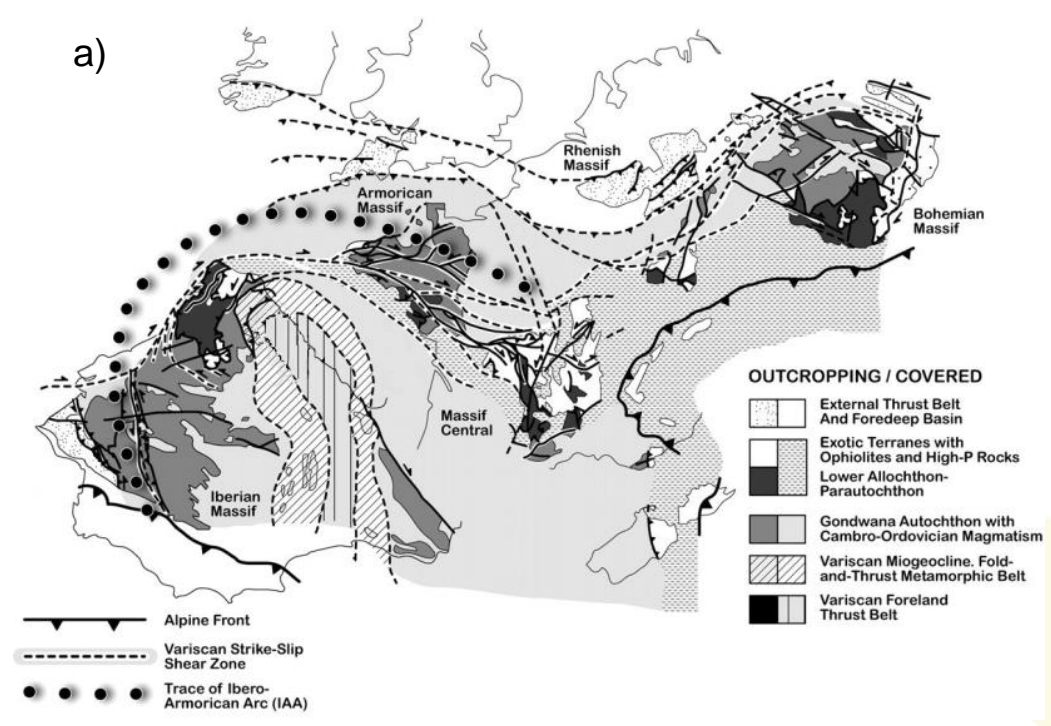

b)
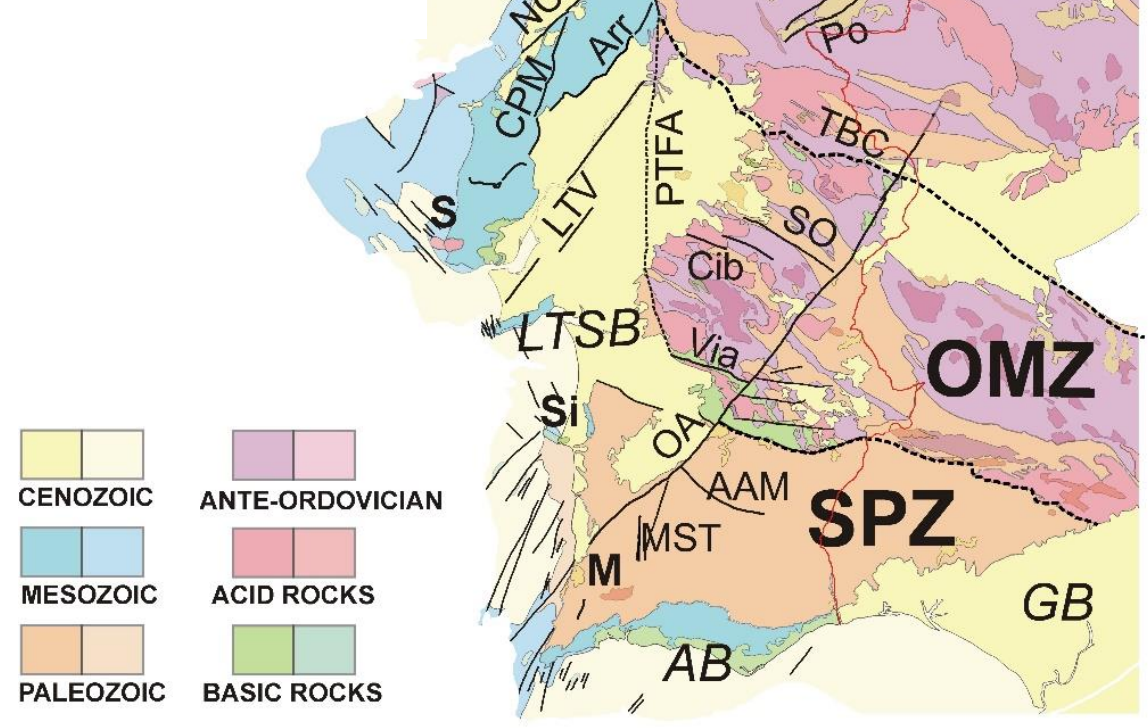

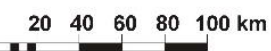

Figure 2 - a) Tectonostratigraphic zonation of the Variscan orogen (after Weil et al., 2010) in southwestern Europe including Iberian Peninsula (original modified from Franke, 1989; Martinez-Catalan et al., 2007). Location of Centro Iberian (CIZ), Ossa Morena (OMZ) and South Portuguese Zones (SPZ); b) Simplified tectonostratigraphic terrane map of Portugal. It is mainly covered by variscan outcrops, belonging to the Iberian Massif, is tectonically divided into several units: GTMZ Galicia-Tras-os-Montes Zone, CIZ Central Iberian Zone, OMZ Ossa-Morena Zone, SPZ South Portuguese Zone. The western and southern limits of the Massif are defined by Mesocenozoic basins, LB Lusitanian Basin and AB Algarve Basin, with several cenozoic basins partially covering, LTSB Lower Tagus and Sado Rivers Basin, GB Gudalquivir Basin, and DB Douro Basin. The main faults/lineaments/aligments affecting western Iberia are: PTFA Porto-Tomar -Ferreira do Alentejo shear zone; TBC Tomar-Badajoz-Córdoba shear zone; PRV Penacova-Régua-Verin Fault system; MVB Manteigas-Vilariça-Bragança fault system; SL Seia-Lousã fault; CBo Cebola-Bogas fault; Po Ponsul fault; NCA Nazaré-Condeixa-Alvaiázere; CPM Candeeiros-Porto de Mós fault; Arr Arrife fault; LTV Lower Tagus Valley fault system; Cib Ciborro fault; SO Serra de Ossa fault; OA Odemira-Ávila fault; AAM Albornoa-AljustrelMessejana Alignment; MST Monchique-Santa Clara fault. The sienitic intrusions of Sintra, Sines and Monchique are marked by S, Si and M (adapted from "Carta Geológica de Portugal", Serviços Geológicos de Portugal, 1992). 

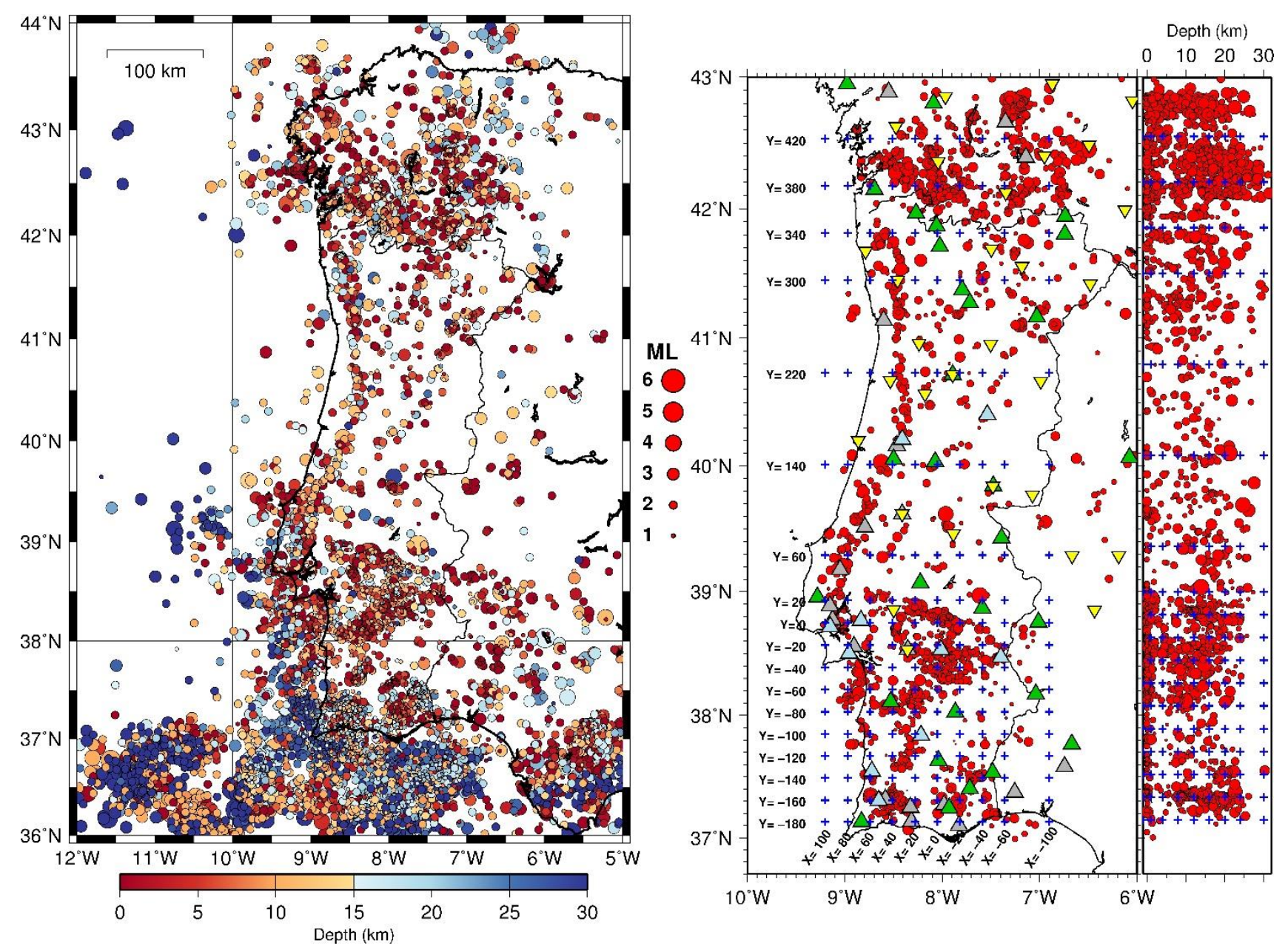

Figure 3 - Left: Seismicity epicentral depth distribution in Portugal from IPMA's catalogue 2000-2014; Right: seismic networks evolution since 2000 with current permanent active stations (green and light blue triangles) and deactivated stations (grey triangles) in Portugal and Spain; the stations from the WILAS and TOPOIBEIRA temporary deployments 2010-2013 are marked with yellow inverted triangles. Also represented are the 2640 selected events for this study and the position of the grid nodes and corresponding $X$ and $Y$ coordinates. 


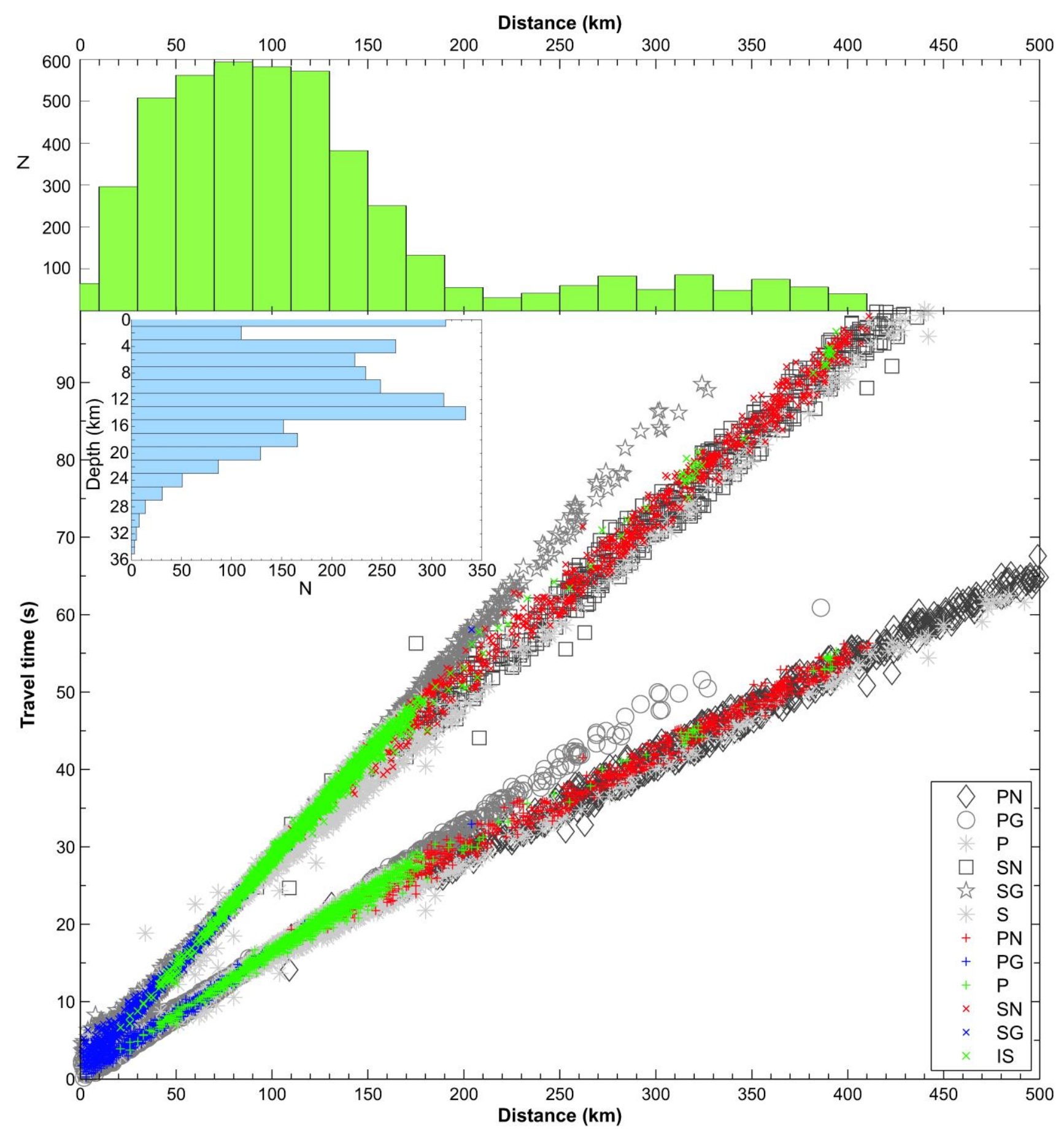

Figure 4 - Histograms of the number of events in terms of distance and depth, bins of 20 and $2 \mathrm{~km}$ range respectively, and distance-time graphic of all phases picked as first $P$ and $S$ arrivals in the selected dataset. The labelling corresponds to the existing identification done by the operator in the catalogue (Pg, Pn, P; Sg, $\mathrm{Sn}, \mathrm{S})$. In the inversion they are all used as $\mathrm{P}$ or $\mathrm{S}$. 


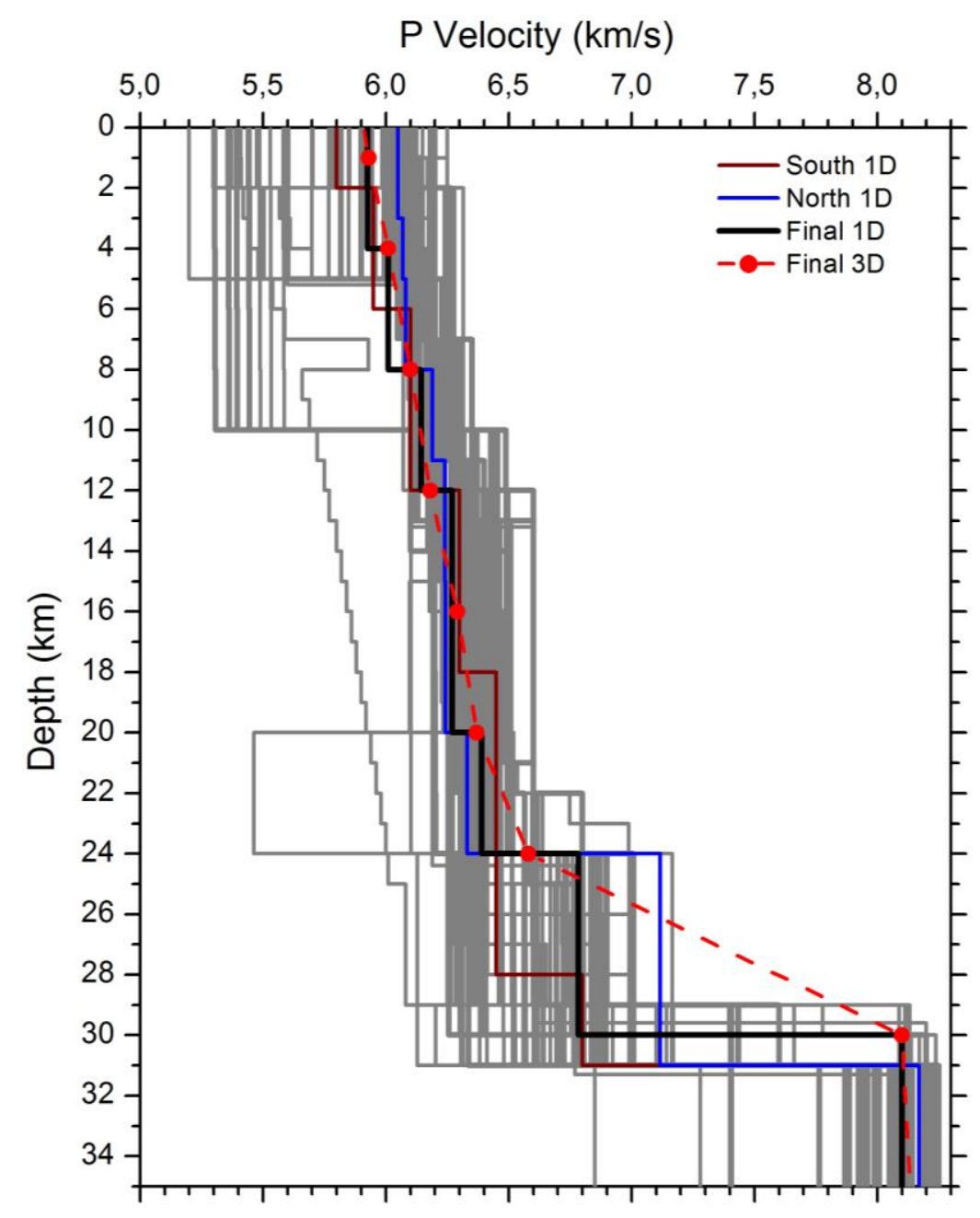

Figure 5 - Graphic Vp-Z with the several tested input models of the 1D inversion with the VELEST code (grey lines). The output models for the two north and south datasets are represented by blue and dark red lines and the final minimum 1D model by a black line, respectively. The adaptation for the input model of the 3D grid is represented by red dots (nodes values) and dashed line (interpolation). 


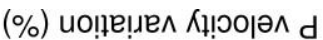

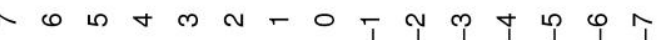
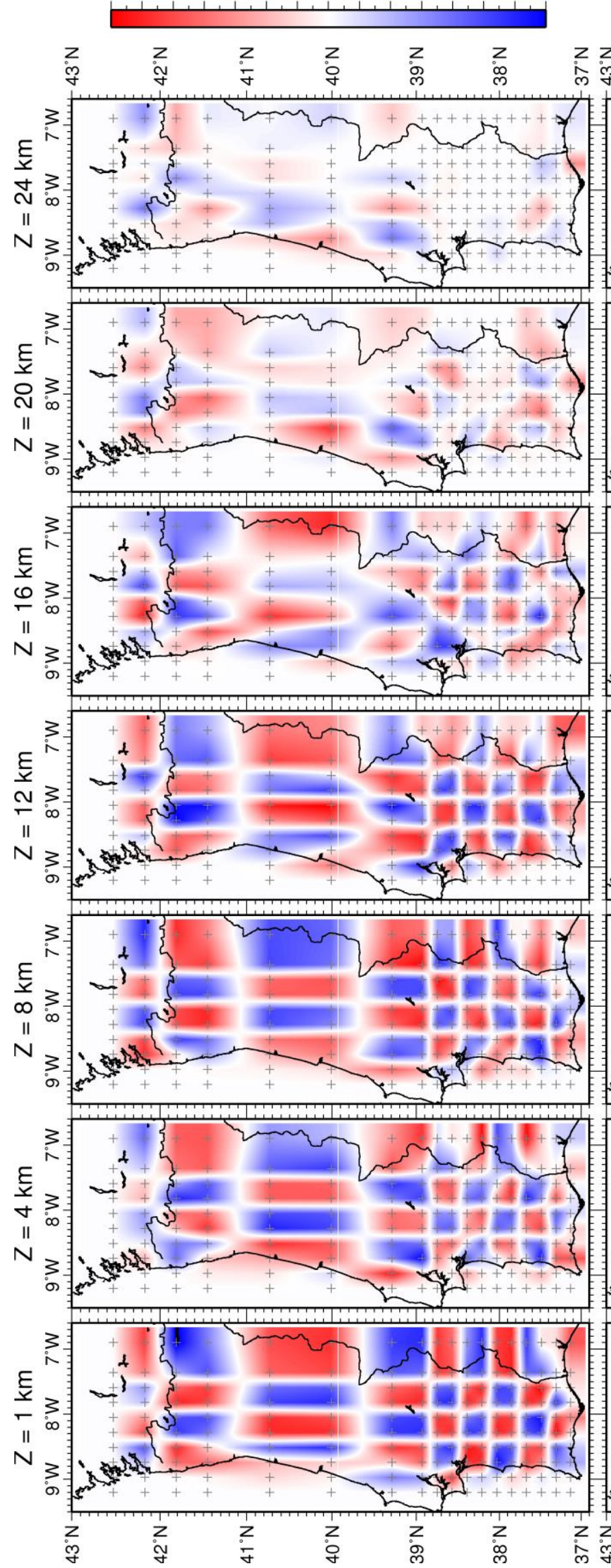

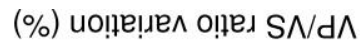

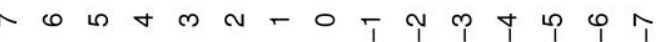

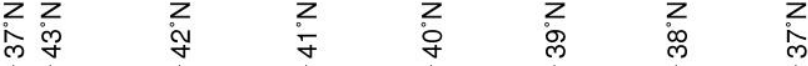
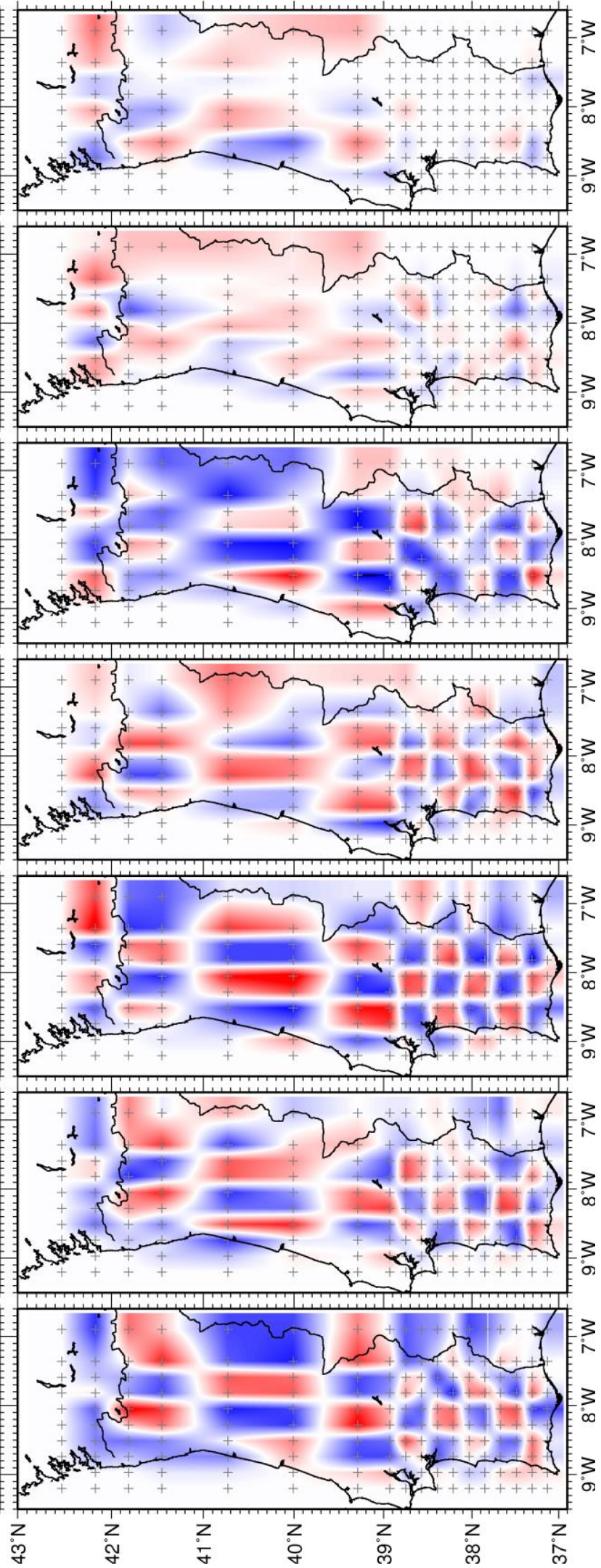

Figure 6 - Checkerboard synthetic tests output for the $\mathrm{Vp}$ (top) and $\mathrm{Vp} / \mathrm{Vs}$ (bottom) models. The represented layers correspond to grid horizontal planes and coincident with the planes of figure 8 . 

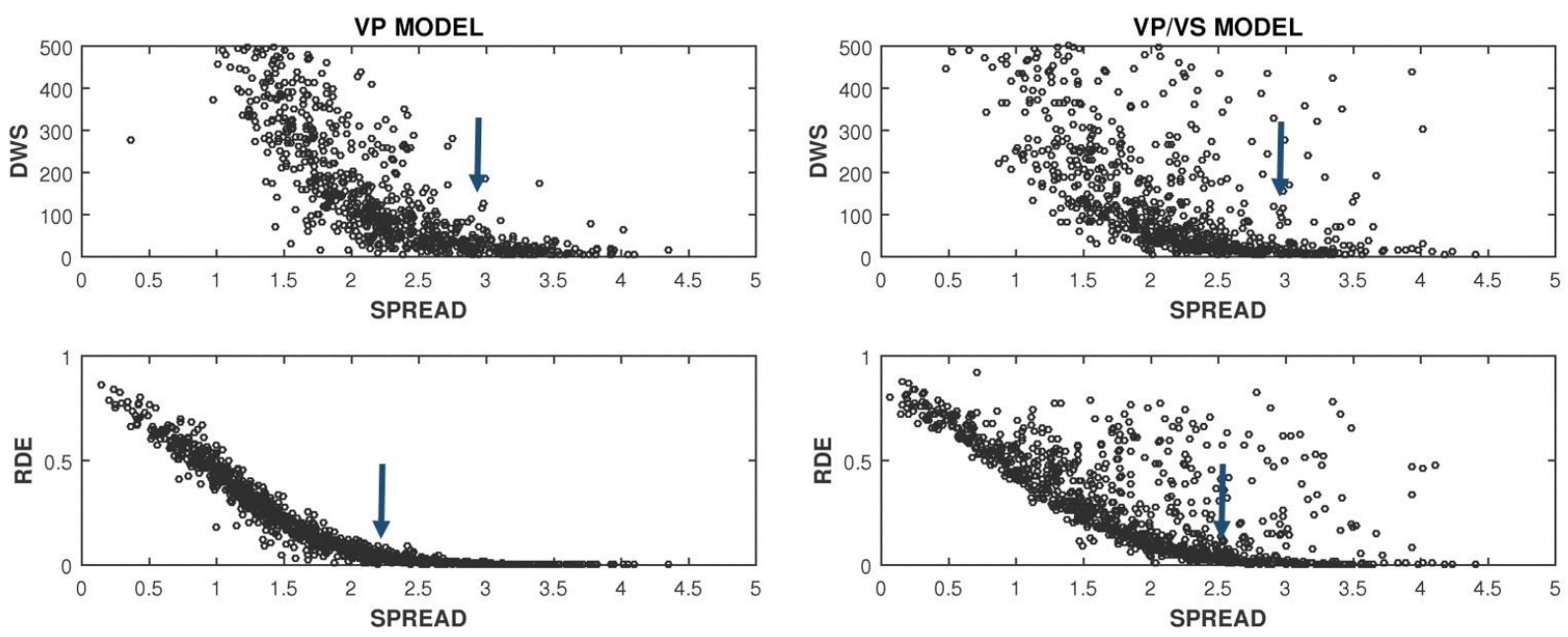

Figure 7 - Plots of the derivative weight sum (DWS) and diagonal element of the resolution matrix (RDE) versus the spread function (SF) values for the $\mathrm{Vp}$ (left) and $\mathrm{Vp} / \mathrm{Vs}$ (rigth) models. The arrows point to the selected threshold values of SF. 
$(\mathrm{s} / \mathrm{uy}) \mathrm{d} \Lambda$

N

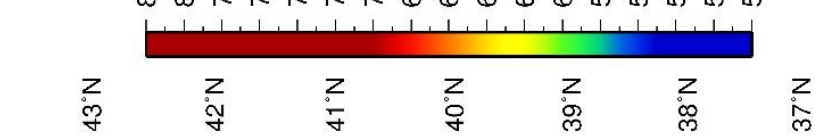

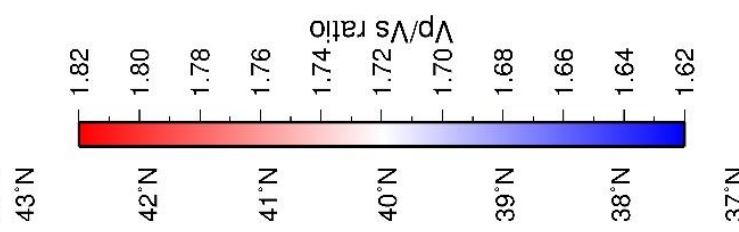
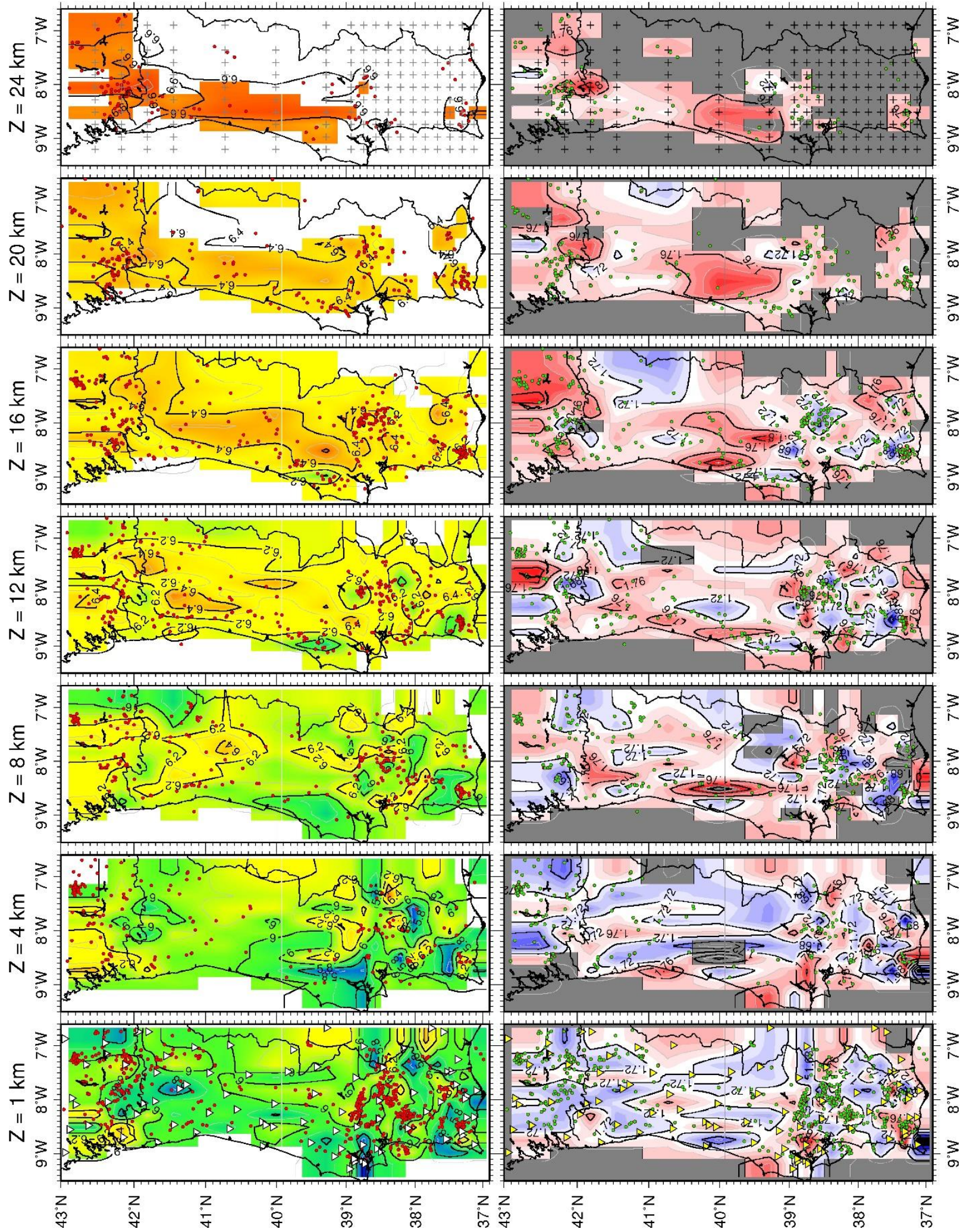

Figure 8 - Final 3D Vp and Vp/Vs models for mainland Portugal and surrounding areas. All nodes with SF higher than the cut-off value ( 2.8 for $\mathrm{Vp}, 3.0 \mathrm{for} \mathrm{Vp} / \mathrm{Vs}$ ) are masked. Models represented on seven horizontal

$X Y$ planes coincident with the grid nodes position, excluding planes $Z=-1$ and $Z=30 \mathrm{~km}$. The relocated earthquakes projected in each layer correspond to events located in a volume $+/-2 \mathrm{~km}$ around the layer, with exception of the upper 1 and $4 \mathrm{~km}$ layers, whose separation is located at $2.5 \mathrm{~km}$ depth, and the deeper layer which contain all events deeper than $22 \mathrm{~km}$. 

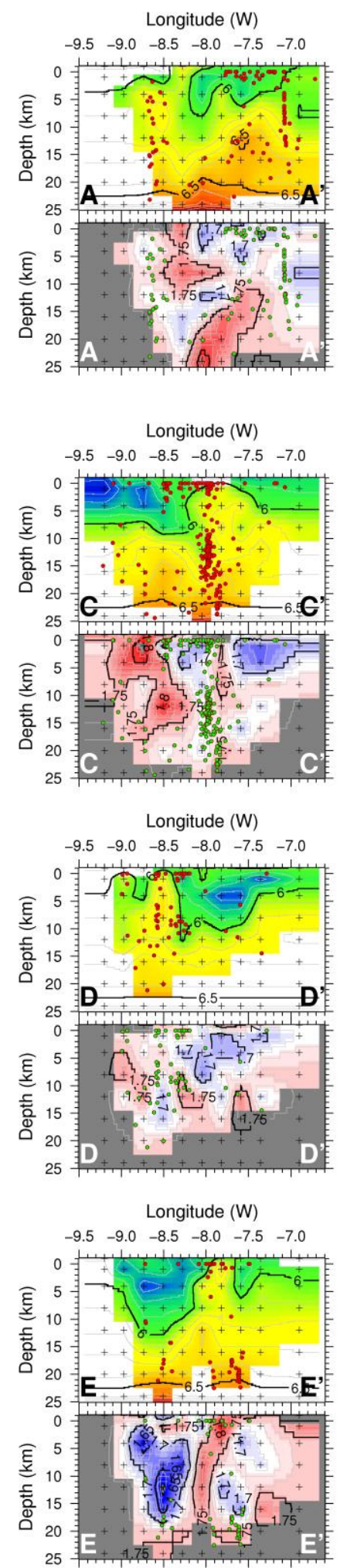
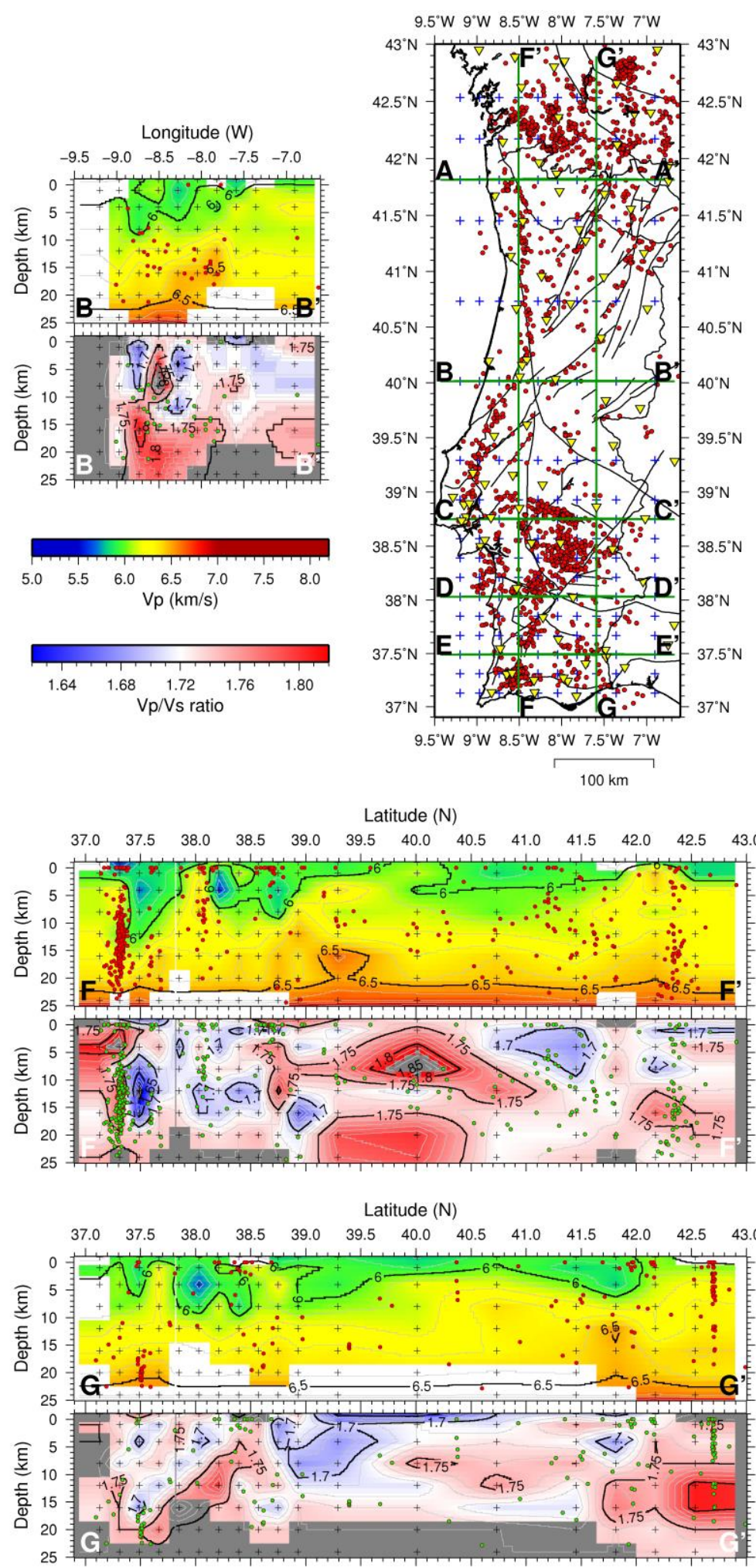

Figure 9a-Vertical profiles of the final 3D Vp and Vp/Vs model. The upper right map presents the relocated epicenters together with the stations and grid, and the position of seven vertical profiles, five $W$-E along constant latitude (A-A' to $\left.E-E^{\prime}\right)$ and two N-S along constant longitude ( $\mathrm{F}-\mathrm{F}^{\prime}$ and $\left.\mathrm{G}-\mathrm{G}^{\prime}\right)$. All profiles are coincident either with $X Z$ or $Y Z$ vertical node-planes.. Nodes with SF higher than the cut-off value (2.8 for Vp, 3.0 for $\mathrm{Vp} / \mathrm{Vs}$ ) are masked. The relocated earthquakes projected in each profile correspond to events located in a volume $+/-10 \mathrm{~km}$ around the slice, with exception of the northern profiles $A-A^{\prime}$ and $B-B^{\prime}$ for which the volume is expanded to $+/-20 \mathrm{~km}$ due to the greater internode distance. Vertical exaggeration of 5:1. 

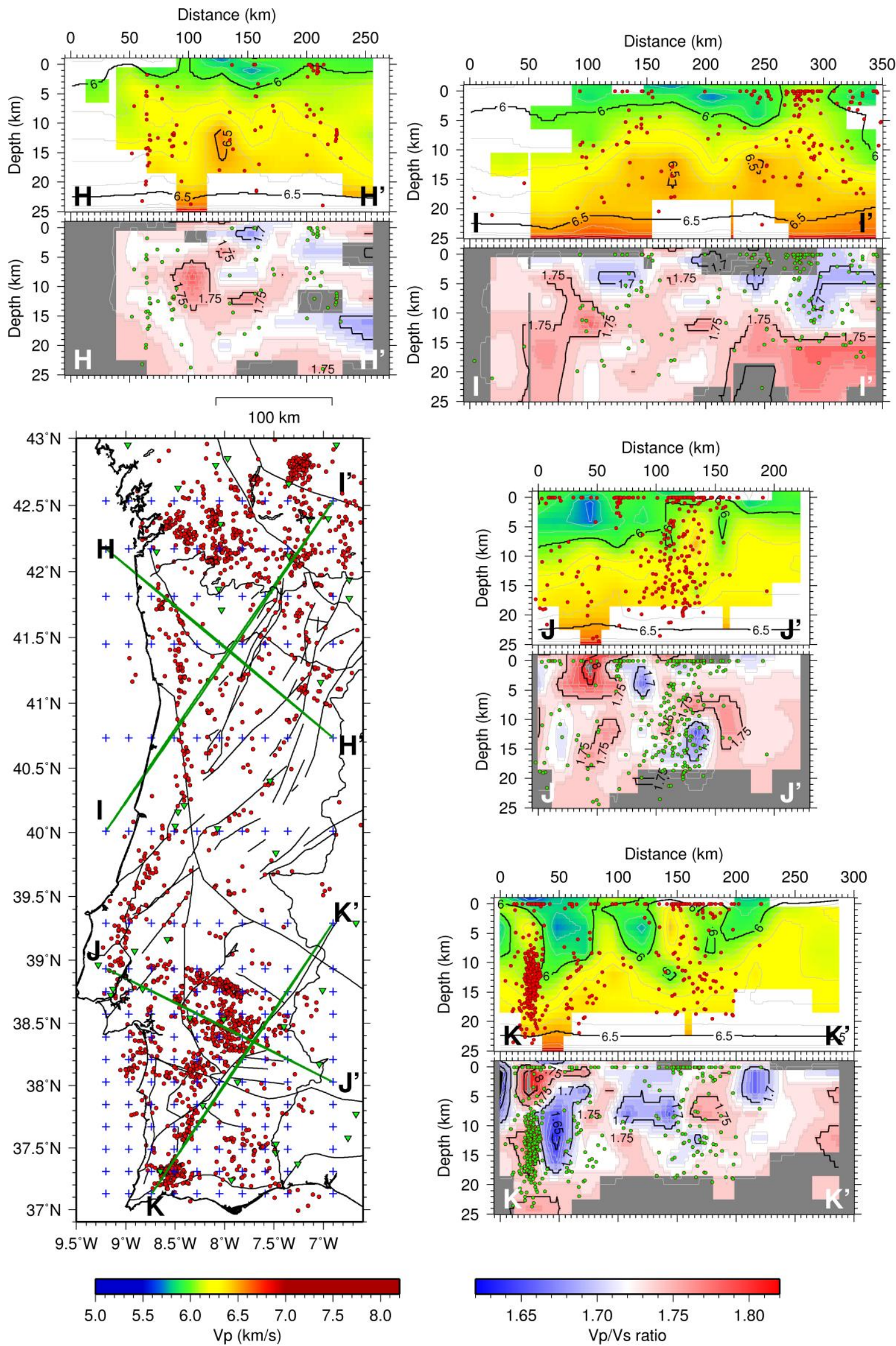

Figure $9 b-V e r t i c a l$ profiles of the final $3 D V p$ and $V p / V s$ model. The bottom left right map presents the relocated epicenters together with the stations and grid, and the position of four vertical profiles oblique to the grid, of either SW-NE or NW-SE directions. Nodes with SF higher than the cut-off value (2.8 for Vp, 3.0 for $\mathrm{Vp} / \mathrm{Vs}$ ) are masked. The relocated earthquakes projected in each profile correspond to events located in a volume $+/-10 \mathrm{~km}$. Vertical exaggeration of 5:1. 

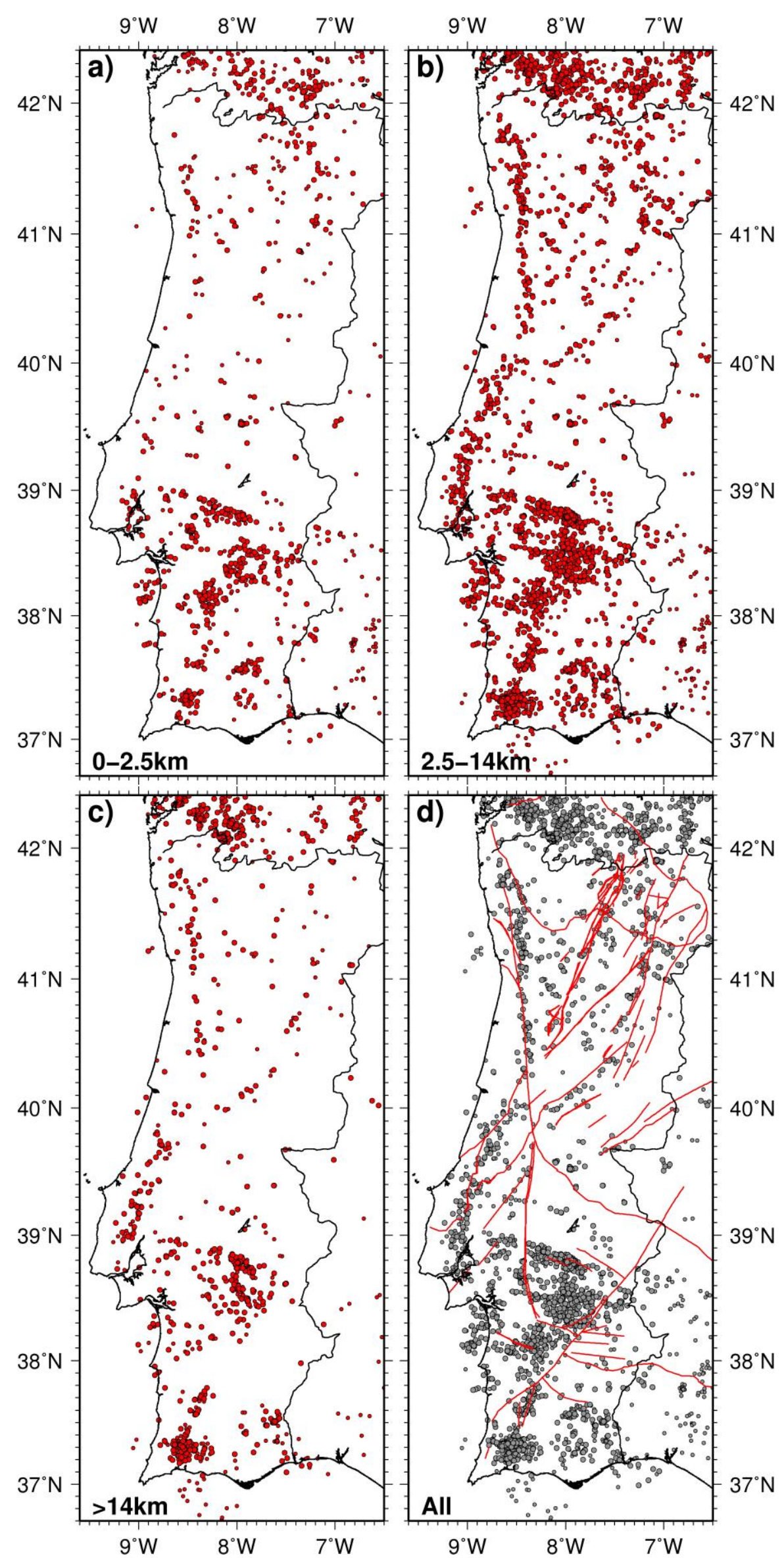

Figure 10 - Map of seismicity distribution of 6375 events, over three depth ranges: a) shallow $(\leq 2.5 \mathrm{~km})$; b) upper-mid crust $(2.5-14 \mathrm{~km})$; c) lower crust $(>14 \mathrm{~km})$; d) superposition of the entire dataset with the lineaments and faults of figure 2 . The additional events relocated with the 3D model are represented with a smaller circles size (see text for details. 